\title{
A família Lemnaceae Gray no Pantanal (Mato Grosso e Mato Grosso do Sul), Brasil ${ }^{1}$
}

\author{
VALI JOANA POTT ${ }^{2}$ e ARMANDO CARLOS CERVI ${ }^{3}$
}

(recebido em 29/07/97; aceito em 03/02/99)

\begin{abstract}
The family Lemnaceae Gray in the Pantanal wetland (Mato Grosso and Mato Grosso do Sul), Brazil.) A survey of aquatic plants belonging to the family Lemnaceae was carried out in the Pantanal wetland (States of Mato Grosso and Mato Grosso do Sul), represented by nine species, divided into four genera. Only two of the reported species had been previously cited for the Pantanal, Wolffiabrasiliensis Wedd. and Lemna valdiviana Phil. The other species are Spirodela intermedia W. Koch, Lemn a aequinoctialis Welw., L. minuta Kunth, in Humb., Bonp. \& Kunth, Wolffiella welwitschii (Hegelm.) Monod, W. lingulata (Hegelm.) Hegelm., W. oblonga (Phil.) Hegelm., and Wolffiacolumbiana H. Karst. Lemnaceae occurs in all 10 subregions of the Pantanal, with a higher number of species in the Nabileque subregion, where soils are more fertile.
\end{abstract}

RESUMO - (A família Lemnaceae Gray no Pantanal (Mato Grosso e Mato Grosso do Sul), Brasil). Realizou-se o levantamento de plantas aquáticas da família Lemnaceae no Pantanal do Mato Grosso e Mato Grosso do Sul, a qual está representada por nove espécies, distribuídas em quatro gêneros. Das espécies encontradas somente Wolffiabrasiliensis Wedd. e Lemna valdiviana Phil. haviam sido registradas no Pantanal. As demais espécies são Spirodela intermedia W. Koch, Lemna aequinoctialis Welw., L. minuta Kunth, in Humb., Bonp. \& Kunth, Wolffiellawelwitschii(Hegelm.) Monod, W.lingulata (Hegelm.) Hegelm., W.oblonga (Phil.) Hegelm. e Wolffia columbiana $\mathrm{H}$. Karst. As Lemnaceae ocorrem em todas as 10 sub-regiões do Pantanal, com o maior número de espécies na sub-região do Nabileque, de solos mais férteis.

Key words - Duckweed, Lemnaceae, Pantanal wetland, taxonomy

\section{Introdução}

A família Lemnaceae Gray compõe-se das menores Angiospermas conhecidas (Engler 1877, Hillman 1961, Melchior 1964, Landolt 1981, 1986, Cook 1990). O nome comum no Brasil, quando utilizado ou conhecido, é "lentilha-d'água".

É uma família pequena, com quatro gêneros e 36 espécies (Landolt 1986). A propagação, em geral, é vegetativa e, por isso e pelo reduzido tamanho das plantas, é uma família problemática e de difícil delimitação dos táxons, devendo sua identificação freqüentemente ser auxiliada por dados sobre sua distribuição geográfica (Landolt 1980). Apresenta distribuição sub-cosmopolita, com centro de dispersão tropical e subtropical na América do Sul. No Brasil, a família está representada pelos seus quatro gêneros: Spirodela, Lemna, Wolffiellae Wolffia

O primeiro autor a descrever flores de Lemna foi Vallisneri em 1714, (Marie-Victorin 1831 apud Landolt 1986). Micheli (1729) também observou flores de

1. Tese de mestrado de V. J. Pott.

2. Embrapa (CPAP) - Centro de Pesquisa Agropecuária do Pantanal, Caixa Postal 109, 79320-900 Corumbá, MS, Brasil Bolsista da Embrapa.

3. Universidade Federal do Paraná, Departamento de Botânica, Caixa Postal 19031, 81531-970 Curitiba, PR, Brasil. Bolsista Pesquisador do CNPq.
Lemna, chamando de Lenticula as plantas com flores e de Lenticularia, as estéreis. Linné (1753) distinguiu quatro espécies, todas pertencendo ao gênero Lemna. Gray (1821) usou o nome Lemnadeae para a família, mas esta forma não está correta. A designação Lemnaceae foi dada por Dumortier (1827).

A primeira monografia foi feita por Schleiden (1839) sobre as espécies conhecidas na época (Wolffia arrhiza L., W. brasiliensis, W. lingulata Hegelm., Lemna paucicostata, L. valdiviana e Spirodela polyrrhiza L.). Hegelmaier (1868) publicou uma extensa monografia, que ainda hoje serve de referência para o estudo das Lemnaceae e em 1878 apresentou, com descrição latina, várias espécies da flora brasileira (Hegelmaier 1878). Giardelli $(1969,1972)$ trabalhou com Lemnaceae na Argentina, citando Wolffia brasiliensis para o Mato Grosso.

Den Hartog \& Van Der Plas (1970) fizeram uma revisão crítica da família. Mantiveram as duas subfamílias (Lemnoideae e Wolffioideae) já aceitas, porém criaram dois novos gêneros Pseudowolffiae Wolffiopsis desmembrando o gênero Wolffiella Essa abordagem não foi aceita por Landolt (1986), porque considerou que a simetria das frondes (Wolffiopsis) e a presença de células de pigmento, duas flores por fronde e apêndice na cavidade floral (Pseudowolffia) não são características suficientes para separar gêneros. Em uma excelente revisão da família, Landolt (1986) examinou 25000 
exsicatas de 124 Herbários de todo o mundo e manteve 2000 clones vivos em Zurique para seus estudos.

Landolt (1986) considerou a especialização das Lemnaceae na adaptação ao ambiente aquático, a série de redução do tamanho das plantas e a redução nas peças florais como caracteres derivados. Propôs que o gênero mais primitivo seria Spirodela, que ainda possui raízes e o mais evoluído, Wolffia, sem raízes. Segundo Landolt (1986), as espécies mais primitivas de cada gênero (Spirodela intermedia, Lemna gibba, Wolffiella neotropica e Wolffia brasiliensis) encontram-se distribuídas nas regiões mais quentes da América do Sul, provável centro de origem da família.

Existem duas teorias acerca da posição sistemática das Lemnaceae dentro das Monocotyledoneae. Segundo Engler (1877, 1899), Maheshwari (1956, 1958, 1959), Daubs (1965), Hegelmaier (1968) e Dahlgren et al. (1985), a família teria um ancestral comum entre as Araceae extintas, tendo o gênero Pistia (Araceae aquática, flutuante e livre) como elo entre as duas famílias. Análises de seqüências de DNA confirmaram a posição filogenética de Lemna junto com Araceae, muito próxima a Pistia (Chase et al. 1993). Recentemente, Mayo et al. (1995) discutiram as relações filogenéticas de Lemnaceae e Araceae, concluindo que as Lemnaceae deveriam ser incluídas, como uma subfamília, na família Araceae. Entretanto, para o propósito deste trabalho as Lemnaceae foram mantidas como família.

As monografias mais recentes de Daubs (1965) e Landolt (1986), que tratam da taxonomia da família em nível mundial, são muito gerais para um tratamento das espécies no nível regional. As Lemnaceae são pouco conhecidas no Brasil, principalmente pela falta de coleta botânica, particularmente no Centro Oeste, em especial no Pantanal.

As Lemnaceae constituem um elo na cadeia trófica, como alimento para pequenos organismos, peixes e aves, e abrigo de microfauna, e também atuam como despoluidoras (Landolt 1986, Landolt \& Kandeler 1987), sendo, portanto, importantes em ecossistemas aquáticos como o Pantanal.

\section{Material e métodos}

A planície do Pantanal cobre uma área de cerca de 140000 $\mathrm{Km}^{2}$. O clima é do tipo Aw de Koeppen, com precipitação anual de $1100 \pm 300 \mathrm{~mm}$, concentrada em novembro-abril, e temperatura média de $32 \pm 3^{\circ} \mathrm{C}$ no verão e $21 \pm 6^{\circ} \mathrm{C}$ no inverno (CadavidGarcia 1984).
Durante seis anos foram coletadas plantas aquáticas no Pantanal, inclusive Lemnaceae, para as quais as coletas foram intensificadas nos anos de 1992/93.

Todas as sub-regiões do Pantanal foram visitadas, via terrestre ou fluvial, com coletas de barco ou a pé na água. Os ambientes de coleta foram os mais variados possíveis, como: baías (lagoas temporárias ou não), vazantes (linha de drenagem), corixos (cursos d'água estacionais), rios, brejos, campos alagados, caixas de empréstimo (escavações para construção de estradas), baceros (ilhas de macrófitas aquáticas) e camalotes (bancos flutuantes de aguapé, Eichornia spp.).

As plantas foram prensadas e/ou conservadas em álcool $70^{\circ}$ GL, ou formol 4\%, ou FAA 50, ou FAA 70, ou solução Transeau, ou solução de bissulfito de sódio/ácido acético (após fixar a cor com sulfato de cobre). Na maioria das vezes, as plantas foram prensadas em papel sulfite e cobertas com celofane. Outra técnica foi usar cola incolor para que as mesmas ficassem aderidas à cartolina.

Para a reidratação do material herborizado usaram-se detergente e água na proporção 1:1. Posteriormente, o material foi lavado e imerso em hipoclorito de sódio a 4\%, para a observação de nervuras das frondes, por luz transmitida em microscópio estereoscópico.

Não existem tipos de Lemnaceae nos herbários brasileiros e, sempre que possível, examinou-se material de tipos solicitado por empréstimo de diversos herbários estrangeiros. Além disto, obteve-se, através do Prof. Dr. E. Landolt (Zurich), uma coleção viva, esterilizada, em tubos de ensaio com agar-agar, de 35 clones de 24 espécies, na maioria brasileiras e que serviu de referência para identificação das espécies. Manteve-se também, no Centro de Pesquisa Agropecuária do Pantanal (CPAP), uma coleção viva de coletas do Pantanal, em frascos Erlenmeyer com água do ambiente natural.

Para a obtenção das fotografias ao microscópio eletrônico de varredura (MEV), após fixar o material em diversos fixadores, usou-se a seguinte técnica: 1) desidratação do material em série etanólica; 2) secagem ao ponto crítico em equipamento Balser CPD 010;3) montagem em suporte de metal de $1 \mathrm{~cm}$ de diâmetro com uma película de adesivo especial; 4) metalização em ouro a vácuo em aparelho Balser Sputtering SCD 300; 5) observação e fotografia em microscópio eletrônico de varredura (Scanning) SEM 505 Philips, no Centro de Microscopia Eletrônica da Universidade Federal do Paraná.

Chaves para a identificação das espécies foram feitas quase que exclusivamente com base nas características vegetativas, dada a dificuldade de encontrar material florido e a ausência de diferenças florais nas diversas espécies.

Foram revisados materiais de empréstimo ou doação dos seguintes Herbários: CEPEC, ESJ, CH, COR, CPAP, CTES, GUA, HB, HUEFS, HURG, IAN, K, MBM, MG, MO, PACA, PEL, R, SF, SP, SPF, UFMT, UPCB, Z,ZT (siglas de acordo com Holmgren et al. 1990).

\section{Resultados e Discussão}

LEMNACEAE Gray nom. cons. Lemnadeae Gray, Nat. Arr. Brit. Pl. 2:729. 1821. Lemnaceae Dumortier in Fl. Belg. p.147. 1827.

Tipo: Lemna L.

Plantas monóicas, andróginas (interpretadas por muitos autores como inflorescências), aquáticas de água doce, flutuantes livres na superfície, ou levemente submersas, onde pequena parte da fronde é 
exposta ao ar, ou completamente submersas, vindo à tona no período da floração. São plantas diminutas, sem diferenciação de caule e reduzidas a um pequeno corpo talóide, por isso chamado de fronde. Frondes simétricas ou assimétricas, reniformes, arredondadas, linear lanceoladas, obtusas, verdes, com ou sem pigmentos castanhos ou avermelhados; bordos lisos ou levemente denteados; lado dorsal aplanado ou levemente convexo, com ou sem papilas; lado ventral achatado ou inflado, com ou sem aerênquima; com um nó, quase ao centro da linha mediana, de onde emergem raízes e nervuras (quando presentes), e novas frondes e flores ; nervuras $0-16(-21)$ a partir do nó até quase o ápice da fronde; fronde-filha às vezes provida de 2 escamas ventrais (profilo), inseridas na base do estípite, desiguais, sendo 1 unida ao lado ventral até o nó; 2 cavidades laterais, aplanadas na base da fronde (Lemnoideae) ou 1 cavidade terminal aplanada ou cônica (Wolffioideae). A propagação é na maioria das vezes por via vegetativa, a partir do tecido meristemático, através de 1 ou 2 cavidades vegetativas (ou reprodutivas), dando origem a frondes-filhas $\left(\mathrm{F}_{1}\right)$, e estas, por sua vez, a outras frondes-filhas $\left(\mathrm{F}_{2}\right)$, e assim sucessivamente. Podem apresentar uma forma latente em condições adversas, chamada de "turion". Nas Lemnoideae uma das cavidades pode dar origem a 1 flor, e então apresenta um profilo ("bráctea espatácea" ou escama membranácea); as flores originam-se na mesma cavidade (bolsa) onde são formadas as frondes-filhas. Normalmente é formada 1 flor por fronde na cavidade do lado esquerdo (-) após formar várias frondes-filhas. Nas Wolffioideae a flor é originada numa cavidade dorsal e sem profilo (em Wolffiella welwitschii há 2 cavidades); geralmente há 2 frondes, ou várias (até 50) unidas entre si por um estípite hialino, efêmero ou não. Nenhuma a muitas (21) raízes, fasciculadas, não funcionais, sem pelos absorventes e protegidas por coifa. Apresentam 1-2 flores por fronde, andróginas (raro unissexuais), geralmente protogínicas. $\mathrm{O}$ androceu compreende 1 estame com antera bilocular, com deiscência apical (Wolffioideae), ou 2 estames com anteras tetraloculares, com deiscência transversal (Lemnoideae); filete curto ou longo e tênue; grão de pólen globular, de 1-52 mm de diâmetro, com 1 poro germinativo e coberto por protuberâncias espinulosas. $\mathrm{O}$ gineceu consta de 1 ovário súpero por flor, globular, monocarpelar, estilete curto, persistente, contendo 1-4(-7) rudimentos seminais, basais, ortótropos, anfítropos ou anátropos; estigma côncavo (afunilado), com 1 gota estigmática no período da polinização. O fruto possui pericarpo seco, geralmente indeiscente, simétrico ou assimétrico, globoso ou lateralmente comprimido, com ou sem alas; opérculo proeminente, com 1-4 sementes. Semente ovóide com ou sem endosperma, com ou sem costeletas longitudinais e nervuras transversais.

A família Lemnaceae é bem distribuída no mundo, com exceção de regiões áridas ou muito úmidas, tendo preferência pelas zonas temperadas, subtropicais e tropicais (Landolt 1986). O centro de dispersão é a América do Sul, com centros secundários na América do Norte, Sul da África e Austrália. O mapa de distribuição das espécies no Pantanal consta na figura 89 . O termo fronde é aceito pela comunidade científica e consta em Font Quer (1953), que diz: “além das Samambaias e Palmeiras, também se dá o nome de fronde ao corpo vegetativo talóide das Lemnaceae".

Chave para os gêneros de Lemnaceae ocorrentes no Pantanal.

1. Plantas com raiz (subfamília Lemnoideae)

$2.2-\infty$ raízes por fronde ..................... Spirodela

2. Apenas uma raiz por fronde ............... Lemna

1. Plantas sem raiz (subfamília Wolffioideae)

3. Fronde aplanada, delgada, curva ... Wolffiella

3. Fronde globosa Wolffia

Spirodela Schleid., Linnaea 13: 391.1839 (nom. gen. cons. prop.).

Espécie tipo: Spirodela polyrrhiza (L.) Schleid.

Plantas aquáticas flutuantes, livres na superfície da água. Frondes 2-5(-7), simétricas ou assimétricas, levemente reniformes a ovadas, achatadas ou infladas, 3-10 x 2,2-8 mm, muitas vezes com células de pigmentos, de cor castanha, na epiderme do lado ventral e nos bordos das frondes; rafídeos e drusas presentes no parênquima; estômatos no lado dorsal; 3-16 nervuras, vistas em frondes clarificadas; frondes unidas por um longo estípite transparente dentro da cavidade vegetativa; crescimento em forma espiralada; escama dorsal presente, desaparecendo em frondes velhas; escama ventral larga, muitas vezes pigmentada. Cada fronde possui de 2-21 raízes fasciculadas, de coifa pontiaguda, das quais 1-3 perfuram o profilo (folha rudimentar) situado na parte ventral da fronde jovem. Flor andrógina, envolta por um profilo (bráctea espatácea) com abertura apical, 
que nasce de uma das 2 cavidades de posição lateral na fronde; androceu com 2 estames, anteras bitecas, tetraloculares, deiscentes por 2 fendas transversais; ovário com 1-4 rudimentos seminais, sendo 1 anfianátropo e os demais anátropos. Fruto achatado, levemente alado, com 1 ou mais sementes de costeletas longitudinais e estrias transversais.

Dentre as Lemnaceae, são as de maior tamanho. Está representado por apenas uma espécie no Pantanal.

Spirodela intermedia W. Koch, Ber. Schweiz. Bot. Ges. 41(1):113. 1932.

Tipo: Montevideo, Arechavaleta 2502, 1/1877 (ZT!, Holótipo; ZT, Isótipo).

Figuras 1-11, 77, 89.

Frondes assimétricas, elíptico-circulares, 3-8,4 x 2,5-6,7 mm e $0,5-1,8 \mathrm{~mm}$ de espessura, 1-1,3 vezes mais longa que larga; até 7 frondes unidas numa planta; epiderme com estômatos anomocíticos; espaços de ar formados por 3-4 camadas de células no lado ventral da fronde, atingindo quase a borda; nervuras 9-12; pigmentos de antocianina no lado ventral e bordos, na planta adulta, viva ou seca. Raízes fasciculadas, 6-21 por fronde, até $3 \mathrm{~cm}$ compr., as 3-5 primeiras perfuram o profilo, o qual desaparece posteriormente; coifa pontiaguda, 1,0$1,3 \mathrm{~mm}$ compr.; traqueídeos no sistema vascular da raiz presentes. Flor 1,5 $\mathrm{mm}$ compr., envolta por um profilo de abertura apical, com rafídeos; androceu com 2 estames de tamanhos diferentes, ca. 0,4 mm compr., antera ca. 0,25 mm larg.; ovário com 2-5 rudimentos seminais, estilete curto, estigma circular. Fruto $1,8-2,0$ x 1,5-1,9 mm e $0,8-1,0 \mathrm{~mm}$ de espessura, levemente alado, 1-3 sementes; sementes ca. $1,5 \times 0,75 \mathrm{~mm}$ e $0,75 \mathrm{~mm}$ de espessura, 15 22 estrias longitudinais.

A espécie é restrita à América do Sul (da Argentina à Venezuela) e América Central, com clima tropical, subtropical e temperado quente, preferindo verão úmido e inverno suave. No Brasil ocorre nos estados do Acre, Amazonas, Mato Grosso do Sul, Pernambuco, Paraná, Rio de Janeiro, Rio Grande do Sul, Santa Catarina e São Paulo. No Pantanal ocorre na sub-região do Nabileque, de solo fértil, especialmente ao sul da Lagoa do Jacadigo, ao longo da estrada MS-454, e na área de inundação do Rio Paraguai. Assemelha-se a $S$. polyrrhiza, em tamanho e forma, por isso muitas vezes é confundida com ela. Ocorre geralmente em água lêntica, ou então em enseadas de rios, entre a vegetação aquática, junto com outras espécies flutuantes e em "taboal", "pirizal" e "caetezal", formando um mosaico a meia sombra. A floração inicia-se em abril e ocorre até outubro, quando frutifica plenamente, apresentando geralmente duas sementes por fruto.

Material examinado - BRASIL: MATO GROSSO DO SUL: Corumbá, faz. Primavera, corixo Rio Verde, V.J. Pott et al. 1789, 7/5/1992 (CPAP, COR, CTES, SI); idem, Lagoa do Jacadigo, V.J. Pott et al. 1817, 21/5/1992, (CPAP); idem, Estrada inacabada MS 454 para Forte Coimbra, $10 \mathrm{~km}$ da BR 262, V.J. Pott et al. 1831, 27/5/1992 (CPAP, UPCB); idem, Estrada MS 454, $8 \mathrm{~km}$ da BR 262, V.J. Pott \& A.A. Bueno Sbr. 1962, 9/10/1992 (CPAP, SP, CH, HBR); idem, Lagoa do Jacadigo, A. Pott et al. 2893, 23/5/ 1987 (CPAP, SP); idem, Estrada MS 454, $10 \mathrm{~km} \mathrm{da}$ BR 262, N.C. Bueno et al. 399, 30/7/1992 (CPAP); BR 262, idem, Estrada para Morrinho, km 747, M.S. Lima 35, 20/9/1987 (COR); idem, BR 262, próx. a Maria Coelho, S. Hamilton \& S. Sippel 8, 20/9/1987 (CPAP); idem, Lagoa do Jacadigo, S.M. Salis \& J.S.V. Silva 652, 3/3/1993 (CPAP); idem, Lagoa do Jacadigo, G.A. Damasceno Jr. s.n., 25/6/1993 (CPAP 10833); idem, fundos do CEUC, enseada do rio Paraguai, V.J. Pott 2108, 6/8/1986 (CPAP); idem, distrito de Albuquerque, Pousada Curupira, V. J. Pott et al. 1856, 28/2/1993 (CPAP, MBM, ICN). URUGUAI: MONTEVIDEO, Arechavaletta 2502, 1/1877 (ZT, Holótipo).

Lemna L., Sp. Pl. ed. 1: 970. 1753.

Espécie tipo: Lemna minor L.

Plantas flutuantes livres na superfície, ou submersas e, então, vindo à superfície na floração. Frondes em grupos de 2-10 ou mais, ou solitárias, simétricas ou levemente assimétricas, arredondadas, elípticas, oblongas, obovadas ou lanceoladas; achatadas ou infladas (gibosas), com ou sem papilas no lado dorsal, até $5 \mathrm{~mm}$ compr.; sem células de pigmento na epiderme; rafídeos presentes no parênquima, drusas ausentes; estômatos no lado dorsal das frondes emersas; nervuras de 1-5(-7); estípite pequeno, caduco ou não, mantendo unidas gerações sucessivas; escama dorsal ausente; abertura das 2 cavidades vegetativas ou reprodutivas, lateralmente na base da fronde, produz frondes latentes. Raiz apenas 1 por fronde, com membrana cilíndrica na base, alada 


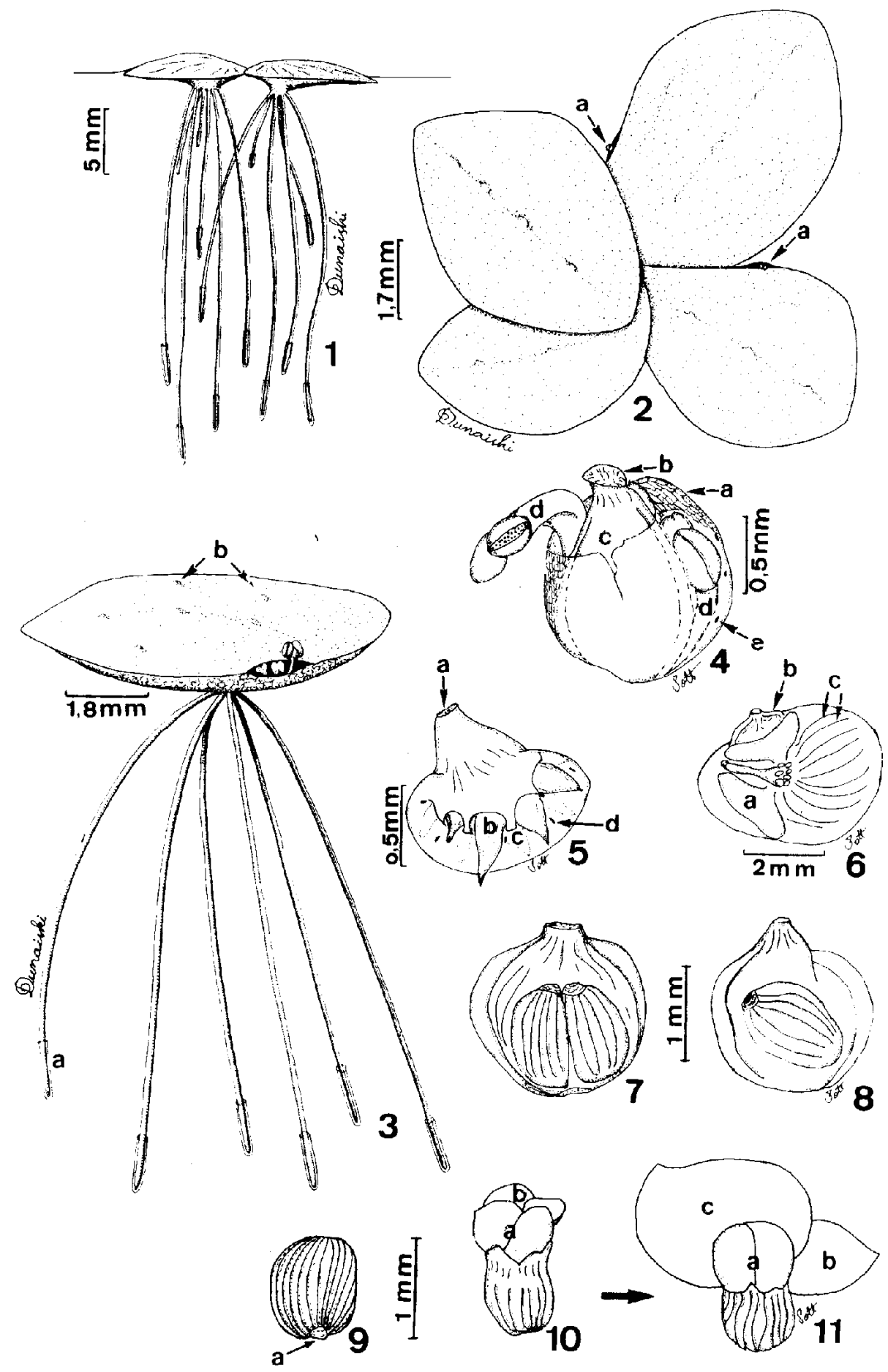

Figuras 1-11. Spirodela intermedia W. Koch 1. Hábito em relação à superfície da água; 2. Vista dorsal (superior): (a) flor; 3. Vista lateral: (a) coifa, (b) papilas; 4. Flor: (a) profilo com abertura apical, (b) estigma, (c) ovário, (d) estame de maturação desigual, (e) ráfides; 5. Profilo da raiz: (a) estípite, (b) raiz primária, (c) raiz secundária (sob profilo), (d) ráfides; 6. Fronde em vista ventral (inferior): (a) cavidade vegetativa, (b) fruto alado, (c) nervuras; 7. Fruto com 2 sementes; 8. Fruto com 1 semente; 9. Semente: (a) chalaza; 10. Germinação: (a) cotilédone, (b) fronde-mãe; 11. Plântula ainda com a semente: (a) cotilédone, (b) fronde-mãe, (c) frondefilha. (V.J. Pott 1962). 
ou não; traqueídeos ausentes. Flor protogínica ou protândrica, envolta pelo profilo com abertura lateral; androceu com 2 estames, anteras bitecas, tetraloculares, deiscentes por duas linhas de deiscência transversal; ovário unicarpelar com 1 rudimento seminal ortótropo ou anfítropo (nas espécies do Pantanal). Fruto simétrico ou não, com 1 ou mais sementes com costeletas longitudinais e estrias transversais.

\section{Chave para as espécies de Lemna}

1. Fronde geralmente sem nervuras ....... L. minuta

1. Fronde com 1 ou 3 nervuras

2. Fronde com 3 nervuras; $2-3$ papilas na face dorsal da fronde, 1 na parte distal da fronde e outra (ou 2) sobre o nó; membrana cilíndrica alada, envolvendo a base da raiz

L. aequinoctialis

2. Fronde com 1 nervura na linha mediana; com ou sem papilas na linha mediana da fronde; membrana cilíndrica não alada, envolvendo a base da raiz L. valdiviana

Lemna aequinoctialis Welw., Ann. Conselho Ultram. 55: 578, 1859.

Tipo: Angola: Distr. Luanda, F. Welwitsch 206, 1858 (STU, Lectótipo; ZT!, BM, G, K!, Isolectótipos).

Figuras 12-18, 78, 89.

Frondes flutuantes livres, assimétricas, ovadas a lanceoladas; $2,0-3,9 \times 1,4-2,4 \mathrm{~mm}, 1,2-2$ vezes mais longa que larga; 2 papilas no lado dorsal, 1 na base e outra maior, próxima à margem distal da fronde; nervuras 3. Raiz 1 por fronde, base envolta por uma película cilíndrica alada. Flor envolta por um profilo de abertura lateral, sem rafídeos; estames de tamanho desigual, 0,42-0,95 mm compr.; ovário 0,37-0,65 x 0,12-0,18 mm. Fruto $0,37-0,45$ x 0,25-0,3 mm; 1 semente de $0,35-0,4 \times 0,20-0,28 \mathrm{~mm}$, de cor castanha, com 8-26 costeletas longitudinais.

A distribuição é pantropical, e tem dispersão através da cultura de arroz irrigado e como planta de aquários. No Pantanal ocorre em todas sub-regiões, coerente com sua ampla distribuição. A identidade da espécie já foi muito confusa, pelo que possui vários sinônimos (Lemna paucicostata Hegelm. e $L$. perpusilla var. paucicostata Hegelm.). Na ausência das papilas, ou em material exsicatado, recorre-se à clarificação da fronde em hipoclorito de sódio (4\%), para observar a presença de 3 nervuras que a diferenciam de $L$. valdiviana e $L$. minuta. Ocorre em populações quase puras, às vezes em associação com Wolffia brasiliensis e $W$. columbiana (submersa); ocorre principalmente em áreas com influência antrópica, em lagoas rasas, próximas às sedes de fazendas e porteiras onde há trânsito, pisoteio e esterco de gado. O banco de sementes, deixado na seca, germina na enchente seguinte, numa explosão de plântulas que cobrem grande parte do corpo d'água e, em pouco tempo (ca. 3 meses), por propagação vegetativa, o cobrem totalmente.

Material examinado - BRASIL: MATO GROSSO: Barão de Melgaço, Baía Chacororé, chácara do Sr. Milton, V.J. Pott et al. 2078, 22/4/1993 (CPAP); idem, Mimoso, Baía Chacororé, V.J. Pott et al. 2079, 22/4/ 1993 (CPAP); idem, Baía Buritizal, Sítio do Sr. Pedro, V.J. Pott et al. 2082, 23/4/1993 (CPAP); idem, Baía Porto de Fora, V.J. Pott et al. 2090, 23/4/1993 (CPAP); Santo Antônio de Leverger, Distrito Cedral, próx. à Praia Grande, V.J. Pott et al. 2059, 21/4/1993 (CPAP); Cáceres, Baía do Iate, Rio Paraguai, V.J. Pott et al. 2048, 22/4/ 1993 (CPAP); Poconé, Porto Cercado, MT 50, 40 km de Cuiabá, N.C. Bueno \& V.J. Pott 385, 4/8/1992 (CPAP); idem, faz. Paraíso, MT 50, $30 \mathrm{~km}$ de Poconé, V.J. Pott et al. 1721, 4/8/1992 (CPAP); idem, Rio Cassange, R. Haase 1, 18/9/1992 (CPAP); idem, Transpantaneira, $5 \mathrm{~km}$ da Base do IBDF, G. Guarim Neto 1062, 19/3/1985 (CPAP). MATO GROSSO DO SUL: Aquidauana, faz. Taboco, fronteira com faz. Iguaçu, R.A. Mauro \& N.R. Guedes 96, 27/3/1993 (CPAP); idem, faz. Pontal, $14 \mathrm{~km}$ do rio Taboco, MS 419, V. J Pott et al. 1694, 31/7/1992 (CPAP); CORUMBÁ, Base de Pesquisa da UFMS, área de inundação próx. Passo do Lontra, G.A. Damasceno Jr. 257, 26/11/1992 (COR); idem, próx. à Base de Pesquisa da UFMS, U.M. Resende \& J.M.S. Jr. 448, 28/3/1991 (UFMS, CPAP); idem, BR 262, próx. ao Morro do Azeite, A. Pott \& A.A. Franco 6212, 29/6/ 1992 (CPAP); idem, Estrada para Carandazal, em frente à porteira no corixo Mutum, V.J. Pott et al. 1662, 28/5/1992 (CPAP, HBR, SPF); idem, faz. Primavera, Rio Verde (corixo), V.J. Pott et al. 1790, 7/5/1992 (CPAP); idem, Porto do Morrinho, braço do rio Paraguai, lado Corumbá, V.J. Pott et al. 1801, 7/5/1992 (CPAP); idem, Ilha da Lagoa do Jacadigo, V.J. Pott et al. 1809, 21/5/ 1992 (CPAP); idem, BR 262, km 632,5, V.J. Pott et al. 1820, 22/5/1992 (CPAP); idem, faz. Firme, V.J. Pott \& A. Pott 1574, 6/2/1990 (CPAP, CTES); idem, faz. Nhumirim, EMBRAPA, área do búfalo, A. Pott 4656, 17/3/1989 (CPAP); idem, Estrada da Manga, MS 228, 

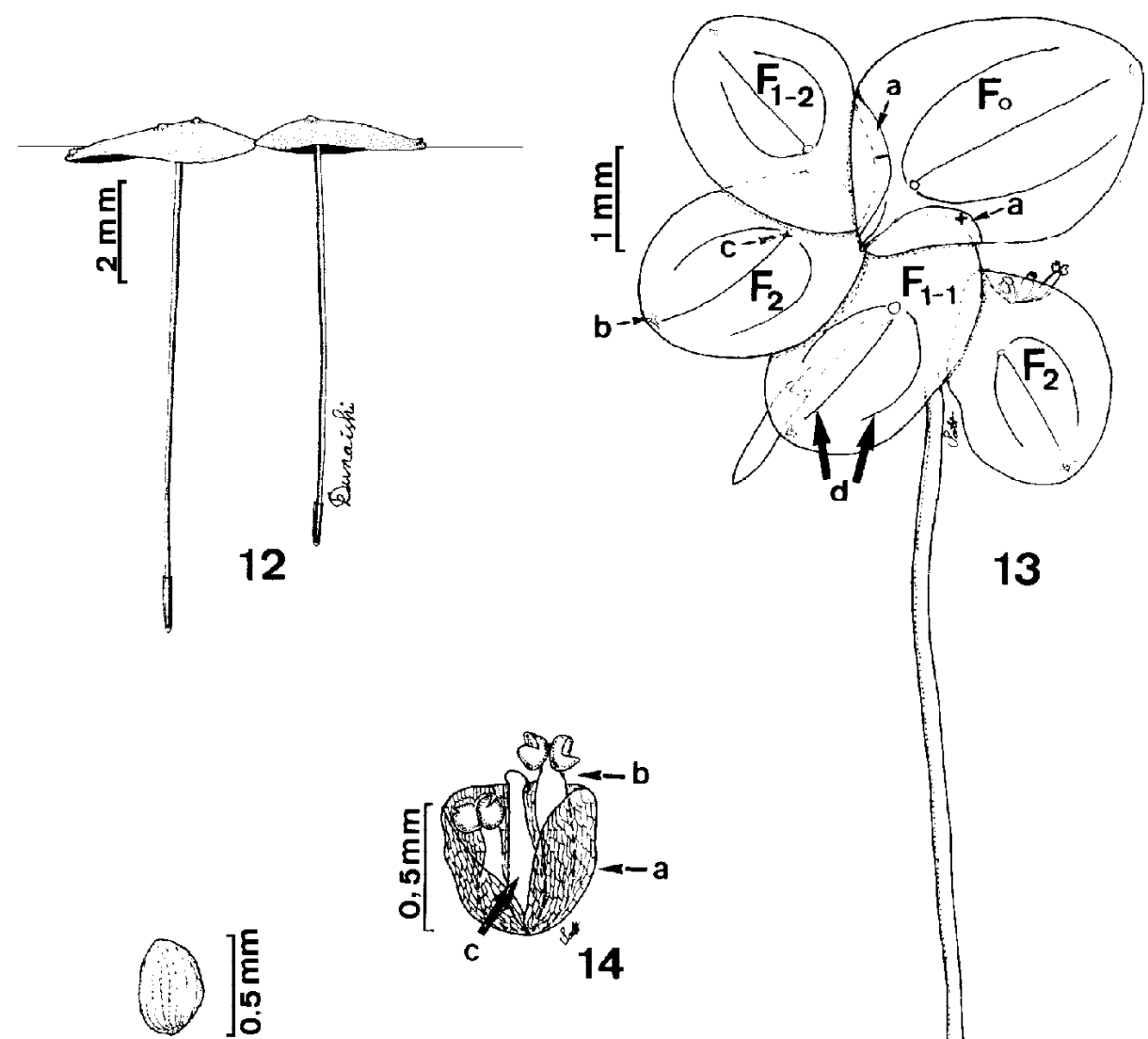

16

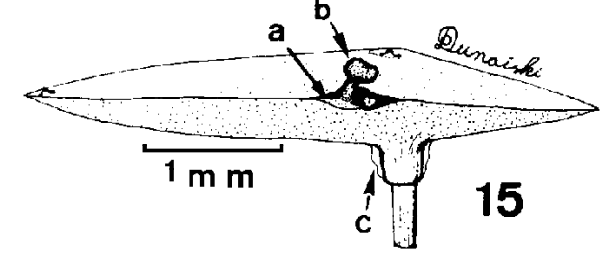

18

Figuras 12-18. Lemna aequinoctialis Welwitsch. 12. Hábito em relação à superfície da água; 13. Vista superior, colônia de frondes (diafanizada): (a) cavidade vegetativa (+) e (-), (b) papila apical, (c) papila basal, (d) nervuras; 14. Flor: (a) profilo aberto lateralmente, (b) estame, (c) ovário; 15. Fronde em vista lateral: (a) cavidade reprodutiva, (b) estame, (c) ala da bainha da raiz; 16. Semente; 17. Semente em germinação: (a) cotilédone, (b) opérculo, (c) fronde-mãe, (d) fronde-filha, (e) papila apical; 18. Plântula: (a) cotilédone, (b) fronde $\mathrm{F}_{0}$, (c) fronde $\mathrm{F}_{1}$. (12-17: V.J. Pott 1978; 18: A. Pott 6164) 
$27 \mathrm{~km}$ da BR-262, N.C. Bueno et al. 353, 11/6/1992 (CPAP, HBR, SPF); idem, faz. Santa Blanca, Rio Novo, próx. ao Porto Esperança, V.J. Pott et al. 1750, 12/4/1992 (CPAP); Ladário, Baía Negra, próx. à transpantaneira (polder), S. Hamilton 6, 2/6/1992 (CPAP, SP, CH); Coxim, junto à sede da faz. Dois Buritis, A. Pott \& A.A. Franco 6179, 28/6/1992 (CPAP). ANGOLA: DISTR. LUANDA: Welwitsch 206, 1858 (ZT, Isótipo).

Lemna valdiviana Phil., Linnaea 33:239. 1864.

Tipo: Chile, Prov. Valdivia, S.Juan, Trembladerilla, R.A. Philippi 1, 1861 (STU, Lectótipo; MO!, Isolectótipo).

Figuras 19-26, 79-80, 89.

Frondes flutuantes ou levemente submersas, oblongo-ovadas, assimétricas na base, 2,0-3,8 $\times 1,2-2,0 \mathrm{~mm}$, $1,5-2,5$ vezes mais longa que larga, 4(-10) unidas entre si; 1 camada de células com aerênquima, de $2 / 3$ da base até o ápice da fronde; raras papilas na linha mediana do lado dorsal, visíveis só em material vivo; 2 cavidades reprodutivas e vegetativas, transparentes na borda com rafídeos; apenas 1 nervura na linha mediana, entre o nó e próximo ao ápice da fronde (até $3 / 4$ da mesma). Raiz até $22 \mathrm{~mm}$ compr., com película cilíndrica, não alada, na base. Estames de tamanhos diferentes (maturação desigual), 0,25 mm compr. Ovário $0,23 \times 0,12 \mathrm{~mm}$, com 1 rudimento seminal. Fruto $0,37-0,43 \times 0,23-0,25 \mathrm{~mm}$, estilete persistente; $1 \mathrm{se}-$ mente, de 0,57 x 0,23 mm, cor castanha, com 15-29 costeletas longitudinais e muitas estrias transversais.

Restrita a clima quente temperado, subtropical e tropical da América do Norte e América do Sul. Frondes jovens às vezes submersas. A nervura única na fronde a diferencia de $L$. aequinoctialis que possui 3, mas é facilmente confundida com L. minuta, necessitando-se a clarificação das frondes para separá-las com segurança. Prefere ambientes lênticos, não profundos, levemente sombreados, como borda de "taboal" e "caetezal". Forma comunidades juntamente com outras Lemnaceae como Wolffiella lingulata, W. oblonga, Wolffia columbiana e Spirodela intermedia, que ocorrem em menor proporção. Flor encontrada ocasionalmente.

Material examinado - BRASIL: MATO GROSSO: Barão de Melgaço, Vila Acurizal, V.J. Pott et al. 1709, 2/8/1992 (CPAP); idem, Baía Acurizal, bacero em frente à Igreja N.S. da Conceição, V.J. Pott et al. 2088, 23/4/1993 (CPAP); Cáceres, Ilha de Taiamã, baía do Arrozal, N. Saddi 7553, 21/7/1986 (CH, CPAP);
MATO GROSSO DO SUL: Corumbá, Lagoa do Jacadigo, A. Pott et al. 2890, 23/5/1987 (CPAP); idem, BR-262, km 747, M.S. Lima 34, 20/9/1987 (COR); idem, MS 454, Estrada inacabada para Forte Coimbra, $10 \mathrm{~km}$ da BR 262, N.C. Bueno et al. 398, 30/6/1992 (CPAP, UPCB, CH, ICN, SI); idem, BR 262, $4 \mathrm{~km}$ da entrada para a MS 454, N.C. Bueno et al. 404, 30/7/1992 (CPAP); idem, faz. Bodoquena, BR 262, km 640, em frente ao Morro do Azeite, V.J. Pott et al. 1940, 12/12/1992 (CPAP); idem, Lagoa do Jacadigo, S.M. Salis \& J.S.V. Silva 649, 3/2/1993 (CPAP, COR, CTES); idem, Estrada MS 454, 9,3 km da BR 262, V.J. Pott \& A. Pott 2021, 12/2/1993 (CPAP, MBM, SP, ICN, SI); idem, Lagoa do Jacadigo, próx. ao morro Tromba dos Macacos, S. Hamilton \& S. Sippel 25, 30/5/1993 (CPAP); idem, Rio Paraguai, $10 \mathrm{~km}$ do Porto da Manga, $7 \mathrm{~km}$ da foz do rio Taquari, N.C. Bueno et al. 346, 11/6/1992 (CPAP); Ladário, Rio Paraguai, terminal da Branave, V.J. Pott et al. 2000, 11/12/1992 (CPAP). CHILE: PROV. VALDIVIA, S. Juan, Trembladerilla, R.A. Philippi 1, 1861 (MO, Isolectótipo).

Lemna minuta Kunth, in Humb., Bonpl. et Kunth, Nov. gen. et sp. 1:372. 1816.

Tipo: Chile, Santiago, R.A. Philippi, 1857 (STU, Lectotipo).

Frondes flutuantes, obovadas, levemente assimétricas na base, de 2-3,9 x 1,6-2-8 mm, 1-2 vezes mais longa que larga, 2-3(-4) unidas entre si; 1-2 camadas de células com aerênquima no mesófilo; nervura geralmente ausente, se presente, muito curta, até $2 / 3$ da base da fronte; raras papilas na linha mediana no lado superior da fronde. Raiz até $9,5 \mathrm{~mm}$ compr. Ovário 0,2-0,4 mm de compr.(Landolt 1986). Fruto excerto $0,6 \times 0,3 \mathrm{~mm}$, estilete persistente; 1 semente.

Ocorre em zonas temperadas a subtropicais da América e como planta introduzida na Europa e Ásia oriental. A espécie é facilmente confundida com $L$. valdiviana, diferenciando-se desta pela ausência da nervura. Ocorre em ambientes lênticos como "taboal" " "caetezal" ou "carandazal" inundável da baía do Castelo. Pode ocorrer com Wolffiella lingulata, W. oblonga e Spirodela intermedia, ou entre outras plantas aquáticas de rio ou corixo.

Material examinado - BRASIL: MATO GROSSO: Poconé, $6 \mathrm{~km}$ próx. a Porto Cercado, V.J. Pott et al. 1727, 4/8/1992 (CPAP); MATO GROSSO DO SUL: Corumbá, Estrada MS 454, 10 km da BR 262, V.J. 

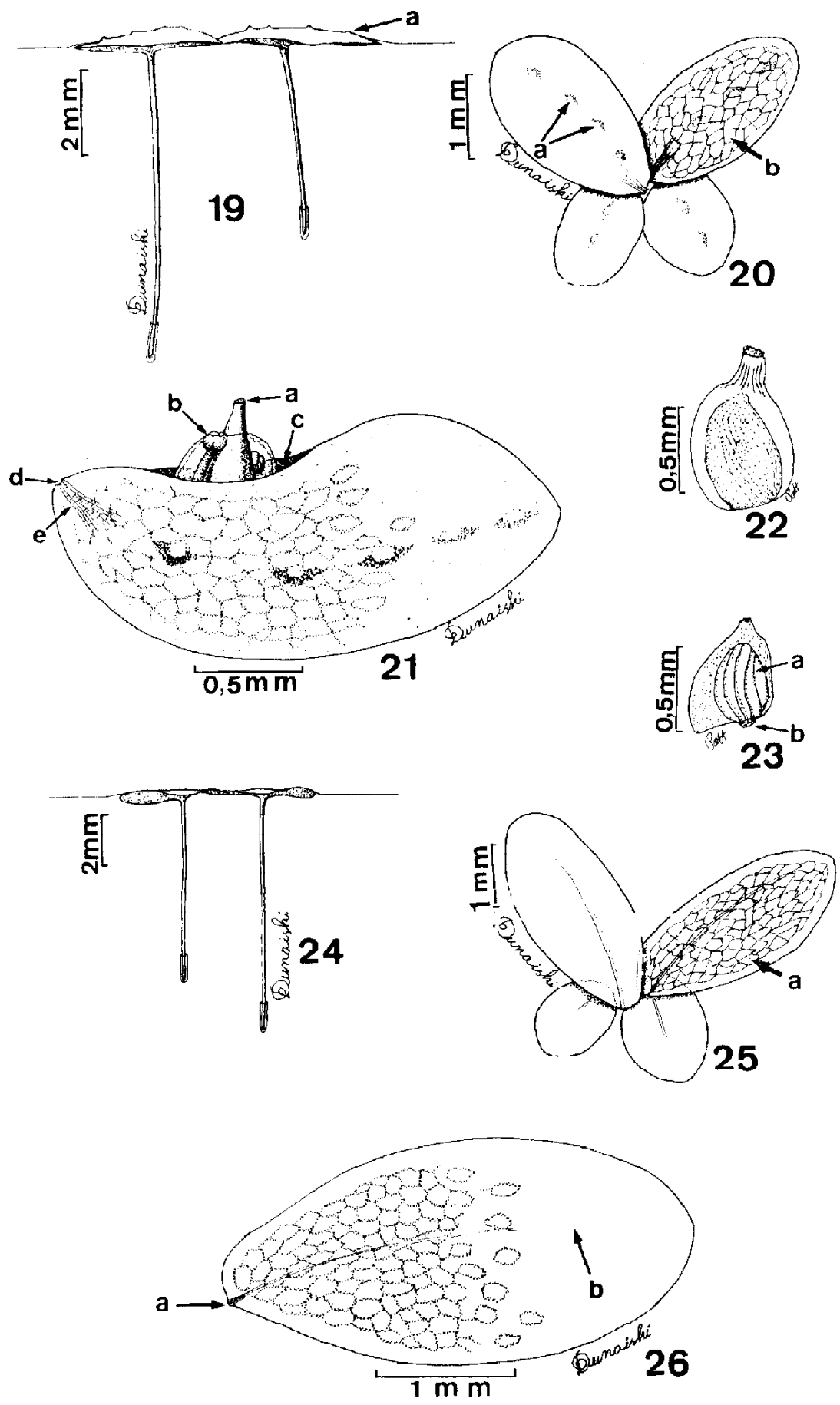

Figuras 19-26 Lemna valdiviana Phil. 19. Planta adulta, flutuante: (a) papilas; 20. Vista dorsal: (a) papilas na linha mediana, (b) aerênquima; 21. Fronde: (a) estigma, (b) estame, (c) cavidade reprodutiva, (d) cicatriz, (e) células alongadas; 22. Fruto imaturo; 23. Semente inclusa no fruto: (a) costeletas longitudinais, (b) chalaza; 24. Planta jovem, levemente submersa, sem papilas, suave ondulada; 25. Vista superior da fronde: (a) aerênquima; 26. Fronde (diafanizada): (a) cicatriz, (b) nervura. (19-23: V.J. Pott \& A.A. Bueno Sobr. 1961; 24-26: V.J. Pott 1977). 
Pott et al. 1833, 27/5/1992 (CPAP, SPF); idem, Porto do Morrinho, braço do Rio Paraguai, V.J. Pott et al. 1797, 7/5/1992 (CPAP); idem, Baía do Castelo, subregião do rio Paraguai, S.M. de Salis \& D. Calheiros 992, 19/6/1998 (CPAP).

Wolffiella (Hegelm.) Hegelm., Bot. Jahrb., 21:303. 1895.

Espécie tipo: Wolffiella oblonga (Phil.) Hegelm.

Plantas flutuantes livres, com frondes submersas na superfície da água, com base emersa quando floridas, delgadas, aplanadas, alongadas, orbiculares a ovadas, lingüiformes, às vezes falcadas; bordo liso ou levemente denticulado; normalmente 2 frondes unidas, ou então muitas unidas pela cavidade vegetativa formando uma colônia de forma estrelada; algumas espécies com células de pigmentos em toda a fronde ou em volta do nó; estômatos próximos à base da fronde quando exposta ao ar; uma cavidade vegetativa triangular e achatada na base da fronde, aberta por uma fenda, da qual emerge a fronde-filha; lado inferior da cavidade vegetativa com uma seqüência de células alongadas transparentes, que conecta o nó e o ponto de inserção na fronde-filha (estípite); em algumas espécies o lado inferior da cavidade forma um prolongamento após a separação das 2 frondes; não há células com rafídeos. Raiz ausente. Flor 1 por fronde, em cavidade floral no lado dorsal da fronde, lateral à linha mediana próxima à base da fronde, ou 2 flores em 2 cavidades, 1 em cada lado da linha ( $W$. welwitshii); sem profilo protetor da flor; estame 1, antera monoteca, bilocular, basifixa; ovário sempre voltado para o lado basal da fronde, com 1 rudimento seminal quase ortótropo, basal, estilete curto, estigma circular, côncavo. Fruto elipsóide.

\section{Chave para as espécies de Wolffiella}

1. Fronde com 2 flores e células alongadas na linha mediana da cavidade vegetativa (arrancar a frondefilha e observar na fronde-mãe, à lupa em diascopia) W. welwitschii

1. Fronde com 1 flor

2. Células alongadas, entre a linha mediana e a borda da parede inferior da cavidade vegetativa; fronde de 1,8-4,3 mm de larg; ângulo da cavidade vegetativa de $80-90^{\circ}$...........W. lingulata

2. Células alongadas, rente à borda da cavidade vegetativa; cicatriz do estípite bem saliente; fronde de 1,1-1,7 mm de larg.; ângulo da cavidade vegetativa de $60-75^{\circ}$ W. oblonga

Wolffiella welwitschii (Hegelm.) Monod, Mém. Soc. Hist. Nat. Afr. Nord. hors. ser. 2:242. 1949.

Tipo: Angola, Distr. Ambriz: prope Quizembo, in Congo, F. Welwitsch 209, 1853. (STU, Holótipo; C, G, H, K!, L, MB, Isótipos).

Figuras 27-37, 81-82, 89.

Frondes flutuantes livres, levemente submersas, simétricas, em forma de lingüeta achatada, membranosas, margens laterais erguidas (como uma sela), base truncada e emersa quando florida, ápice arredondado, pendente na água, 3,2-6,5 x 2,5-5,7 mm, $1,25-1,75$ vezes mais longa que larga; $2-3$ frondes unidas entre si; frondes floridas menores; espaços de ar até quase a metade da fronde; ângulo da cavidade vegetativa de $90-120^{\circ}$; seqüência de células alongadas na linha mediana da parede inferior da cavidade vegetativa, terminando em cicatriz do estípite; células de pigmento presentes na epiderme; com ou sem estômatos na base da fronde, quando emersa. Flores 2 por fronde, 1 em cada lado da linha mediana, floração simultânea; estame $0,37-0,50 \mathrm{~mm}$ compr.; ovário $0,45-0,75 \times 0,10-0,15 \mathrm{~mm}$. Fruto 0,37 x $0,25 \mathrm{~mm} ; 1$ semente, $0,25 \times 0,23 \mathrm{~mm}$.

Ocorre nas regiões tropicais da África e Américas. Característica marcante da espécie são as 2 flores e, na ausência destas, pode ser identificada pela posição mediana da seqüência de células. Frondes estéreis, a olho nu, podem ser confundidas com $\mathrm{Wol}$ ffiella lingulata, pelo seu formato curvo. A espécie não é freqüente no Pantanal. Pode ocorrer associada com L. aequinoctialis. Floresce de junho a outubro.

Material examinado - BRASIL: MATO GROSSO DO SUL: Corumbá, BR 262, 4 km da entrada da estrada para Forte Coimbra, N.C. Bueno et al. 403, 30/7/1992 (CPAP); idem, faz. Fazendinha, estrada inacabada para Forte Coimbra (MS 454), 11,5 km da BR 262, V.J. Pott \& A.A. Bueno Sbr. 1967, 9/10/1992 (CPAP, UPCB); idem, Estrada MS 454, 11,2 km da BR 262, V.J. Pott \& A. Pott 2025, 13/2/1993 (CPAP, MBM); idem, Estrada MS 454, 10,7 km da BR 262, V.J. Pott \& A. Pott 2030, 13/2/1993 (CPAP); faz. Alegria, defronte à sede, A. Pott \& F. Kahn 6163, 16/5/1992 (CPAP); idem, faz. Alegria, defronte à sede, A. Pott, 6449, 10/6/1993 (CPAP, CH, SI); idem, faz. Firme, estrada MS 228, A. Pott 6453, 10/6/1993 (CPAP, SP, ICN); idem, Estrada da Manga, MS 228, 29 km da 

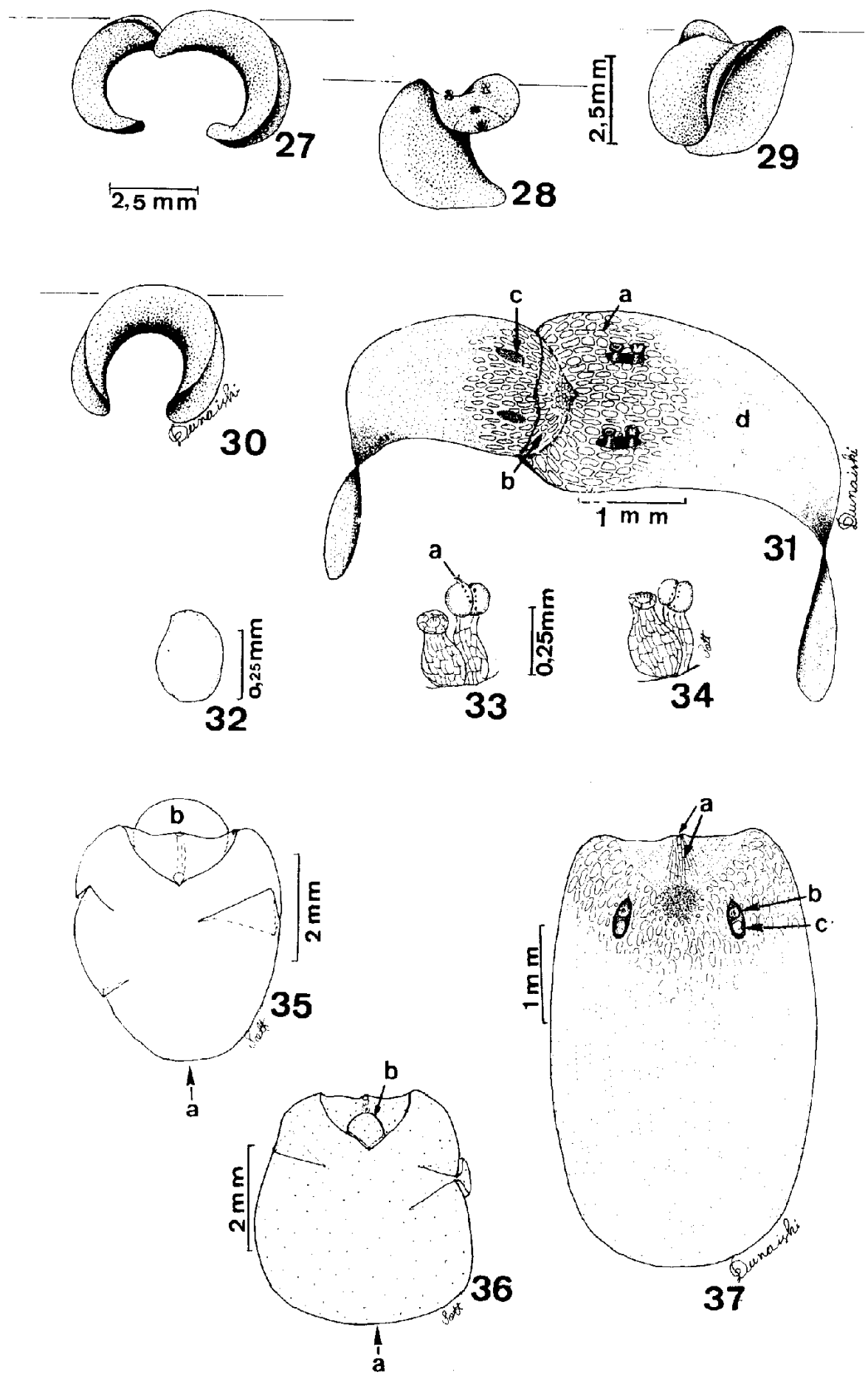

Figuras 27-37. Wolffiella welwitschii (Hegelm.) Monod. 27. Vista lateral de duas frondes (mãe e filha), em forma de sela, parcialmente submersas; 28. Fronde florida; 29. Vista frontal da fronde; 30 . Vista lateral da fronde, em relação à superfície da água; 31 . Frondes em perspectiva superior: (a) aerênquima, (b) cavidade vegetativa, (c) flor jovem na fronde-filha ( $\left.F_{1}\right)$, (d) fronde-mãe com 2 flores; 32. Semente; 33. Flor: (a) pigmentos; 34. Flor; 35. Fronde, vista sob lamínula: (a) base arredondada, (b) fronde-filha; 36. Fronde, vista sob lamínula: (a) base truncada, (b) fronde-filha dentro da cavidade vegetativa; 37. Vista superior da fronde sem fronde-filha: (a) posição mediana da cicatriz (células alongadas), (b) ovário, (c) estame. (A. Pott \& F. Kahn 6163). 
BR 262, N.C. Bueno et al. 519, 11/6/1992 (CPAP). ANGOLA: DISTRITO AMBRIZ: próximo a Quizembo, in Congo, F. Welwitsch 209, 1853 (K, Isótipo).

Wolffiella lingulata (Hegelm.) Hegelm., Bot. Jahrb. 21:303. 1895.

Tipo: México, L. Hahn, 5/1868 (STU, Holótipo).

Figuras 38-49, 83, 89.

Frondes flutuantes livres, submersas, membranosas, em forma de lingüeta, margens laterais erguidas; base levemente truncada obliquamente (por isso levemente assimétrica), ápice arredondado ou, às vezes, mais estreito que a base; fronde florida, com a parte basal emersa, parte distal curva, pendente na água; frondes floridas mais estreitas e levemente assimétricas, geralmente solitárias; duas frondes unidas (raramente três); 3,3-5,0 x 1,6-3,7 mm, de 1,252,5 vezes mais longa que larga; espaços de ar até a metade ou 2/3 da fronde a partir da base (raramente mais longa que larga); ângulo da cavidade vegetativa de $80-90^{\circ}$; seqüência de células alongadas situadas entre a linha mediana e a borda da parede da cavidade vegetativa (nunca na borda); com células de pigmento na epiderme (melhor vistas em frondes secas ou em formol 4\%); com ou sem estômatos, localizados lateralmente na base da fronde quando emersa. Flor 1 , situada dorsalmente no lado direito ou esquerdo da linha mediana da fronde; estame $0,40 \mathrm{~mm}$ de compr., antera $0,25 \mathrm{~mm}$ diâm.; ovário $0,37 \times 0,15 \mathrm{~mm}$.

Distribuída pelas regiões subtropicais e tropicais da América, com invernos suaves. Apresenta grande amplitude de variação na forma da fronde; o material do Pantanal é maior que descrito por Hegelmaier, porém menor que na descrição de Landolt. Landolt (1986) comenta que parece haver uma relação entre a razão compr./larg. e o tipo de clima. Em climas frios a razão é maior, o que explicaria a razão menor, pelo clima quente do Pantanal. Ocorre principalmente associada a raízes de macrófitas aquáticas. Floresce de fevereiro a setembro, com pico em maio.

Material examinado - BRASIL: MATO GROSSO: Barão de Melgaço, Baía de Buritizal, V.J. Pott et al. 1708, 2/8/1992 (CPAP); idem, Baía Buritizal, sítio São Pedro, V.J. Pott et al. 2081, 23/4/1993 (CPAP); idem, Vila Acurizal, área de inundação, V.J. Pott 1710, 2/8/ 1992 (CPAP, SP); idem, Baía Acurizal, em frente à Igreja N.S. da Conceição, V.J. Pott 2089, 23/4/1993 (CPAP); Poconé, MT 50, a $6 \mathrm{~km}$ do final da estrada para Porto Cercado (Porto), V.J. Pott et al. 1726, 4/8/
1992 (CPAP); MATO GROSSO DO SUL: Corumbá, faz. Leque, baía do Cocho, V.J. Pott et al. 1201, 8/ 12/1989 (CPAP); idem, BR 262, km 747, estrada para Morrinho, M.S. Lima 34, 20/9/1987 (COR); idem, faz. Primavera, Rio (corixo) Verde, $6,5 \mathrm{~km}$ da MS 454, V.J. Pott et al. 1791, 7/5/1992 (CPAP); idem, faz. do Sr. Rolindo, MS 454, $13 \mathrm{~km}$ da BR 262, V.J. Pott \& A.A. Bueno Sbr. 1971, 9/11/1992 (CPAP); idem, Corixo Mutum, V.J. Pott et al. 351, 29/9/1987 (CPAP); $500 \mathrm{~m}$ leste de Albuquerque, V.J. Pott et al. 1854, 28/2/1993 (CPAP, UPCB, MBM, $\mathrm{CH}$ ); idem, Lagoa do Jacadigo, próx. ao morro Tromba dos Macacos, S. Hamilton \& S. Sippel 28, 30/5/1993 (CPAP); idem, Lagoa do Jacadigo, G.A. Damasceno Jr. s.n., 25/6/1993 (CPAP 10834, ICN); idem, $10 \mathrm{~km}$ do rio Paraguai e $7 \mathrm{~km}$ da foz do rio Taquari, N.C. Bueno et al. 347, 11/6/1992 (CPAP); idem, $10 \mathrm{~km}$ do rio Paraguai e $7 \mathrm{~km}$ da foz do rio Taquari, N.C. Bueno et al. 361, 11/6/1992 (CPAP); idem, Braço da baía do Castelo, V.J. Pott et al. 1771, 5/ 5/1992 (CPAP); Ladário, Antiga CODRASA, quase final do Polder, $12 \mathrm{~km}$ da BR-262, V.J. Pott \& A. Pott 1981, 31/10/1992 (CPAP); idem, Porto de Ladário, terminal da Branave, V.J. Pott et al. 2001, 11/12/1992 (CPAP); idem, BR 262, km 630, V.J. Pott \& A. Pott 1993, 22/11/1992 (CPAP); Miranda, BR $262, \mathrm{~km} 562$, próx. à ponte do rio Miranda, V.J. Pott \& A. Pott 1672, 13/7/1992 (CPAP).

Wolffiella oblonga (Phil.) Hegelm., Bot. Jahrb. Syst. 21:303. 1895.

Tipo: Chile, Santiago do Chile, R.A. Philippi, 5/ 1857. (STU, Lectótipo; BM, G, GOET, LE, MEL, MO!, S, SGO, UPS, ZT, Isolectótipos; K!, Síntipo).

Figuras 50-57, 84, 89.

Frondes flutuantes livres, submersas, assimétricas, levemente falcadas; fronde florida solitária, de base emersa, base oblíqua, ápice arredondado ou afilado, fronde levemente curvada; 2-3(-8) frondes unidas, muitas vezes em forma estrelada; 3,3-5,5 x 1,0-1,8 mm larg., 2,75-4,5 vezes mais longa que larga; ângulo da cavidade vegetativa $60-75^{\circ}$; seqüência de células alongadas situadas ao longo da borda da cavidade vegetativa; cicatriz do estípite bem visível, com pigmentos; células de pigmento castanho na superfície da fronde; com ou sem estômatos. Flor 1, no lado direito ou esquerdo da linha mediana; estame $0,5 \mathrm{~mm}$ compr., antera com linha de deiscência pigmentada; ovário $0,45 \times 0,2 \mathrm{~mm}$; 


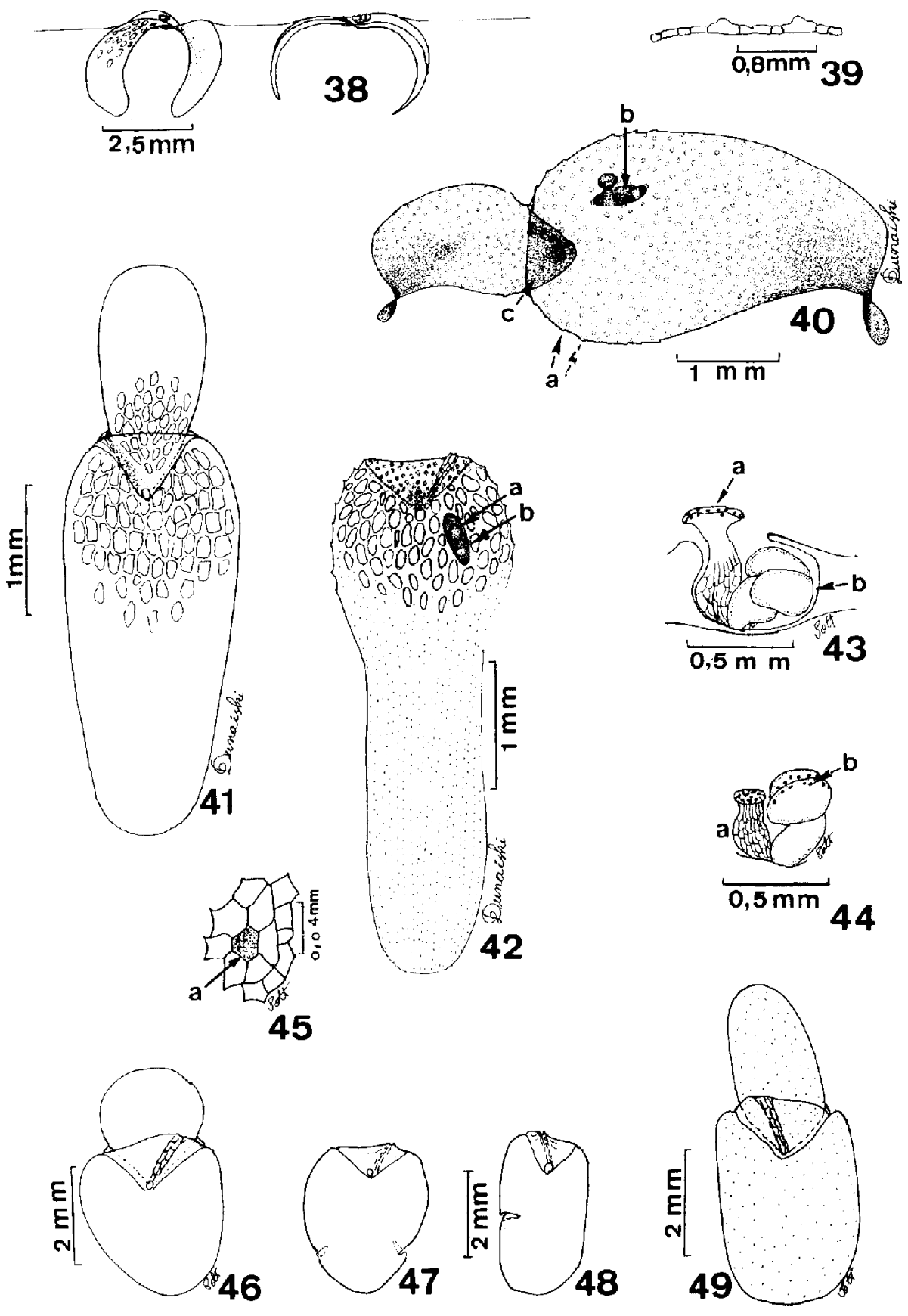

Figuras 38-49. Wolffiella lingulata (Hegelm.) Hegelm. 38. Hábito em relação à superfície da água; 39. Células denticuladas da borda da fronde; 40. Fronde vista em perspectiva superior: (a) bordo levemente denticulado, (b) cavidade floral, (c) cavidade vegetativa; 41. Vista superior de fronde estéril; 42. Vista superior de fronde fértil: (a) estigma, (b) antera; 43. Flor, na cavidade floral: (a) estigma, com células de pigmento, (b) estame jovem; 44. Flor: (a) ovário, após a ântese, (b) antera com pigmentos; 45. Epiderme: (a) células de pigmento (miriofilina); 46-49. Diversos formatos de frondes. (38-45: V.J. Pott 1971; 46-49: V.J. Pott 1708). 

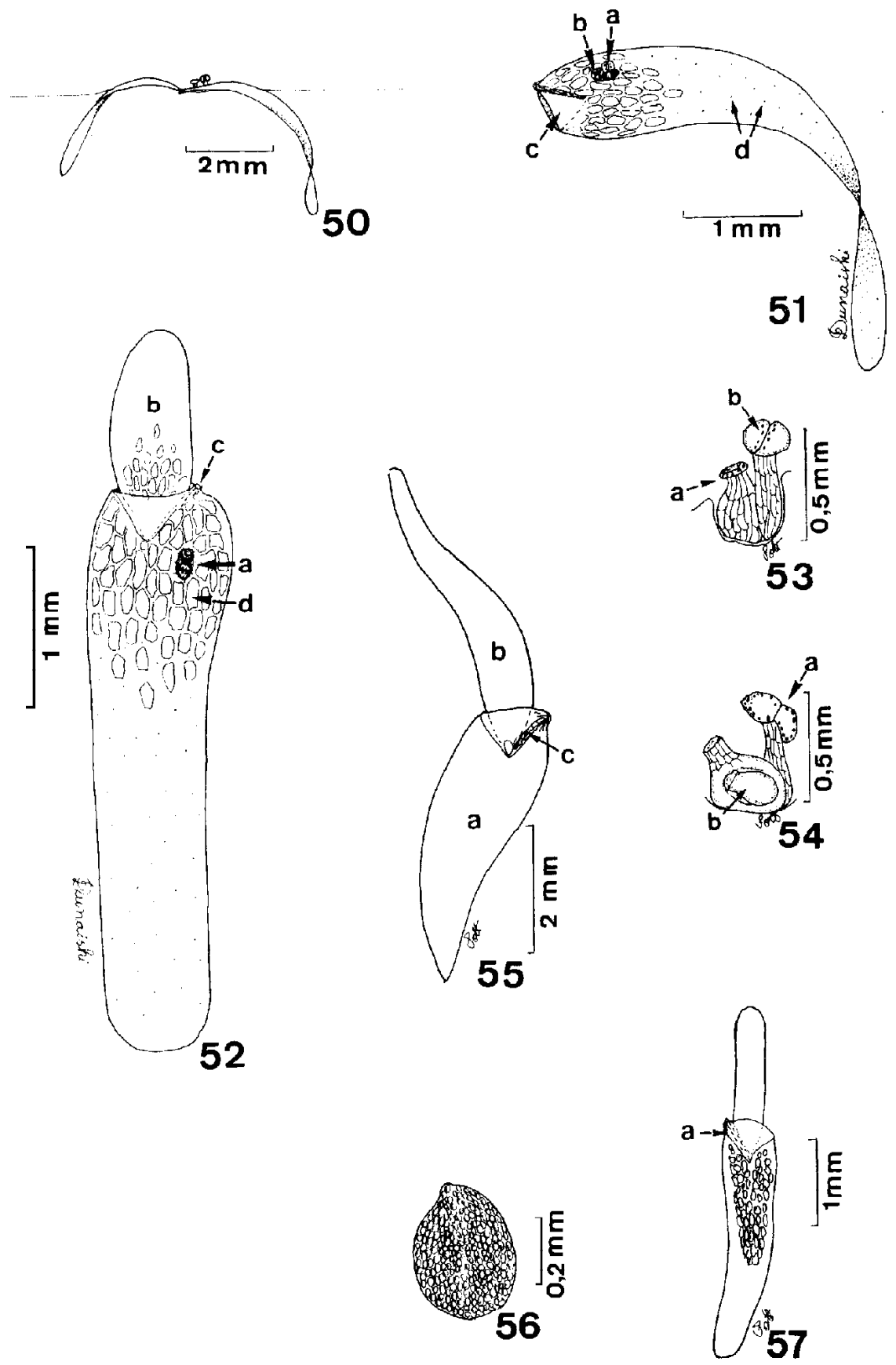

Figuras 50-57. Wolffiella oblonga (Phil.) Hegelm. 50. Hábito em relação à superfície da água; 51. Fronde em perspectiva superior: (a) estame, (b) estigma, (c) cavidade vegetativa, (d) células de pigmento; 52. Fronde de ápice arredondado, vista superior: (a) flor, (b) fronde-filha, (c) cicatriz, (d) células; 53. Flor: (a) estigma com pigmentos, (b) antera com pigmentos; 54. Flor: (a) estame aberto após a ântese, (b) fruto com semente imatura; 55. Fronde de ápice afilado: (a) fronde-mãe, (b) fronde-filha, (c) células alongadas; 56. Semente; 57. Fronde de formato diverso: (a) células alongadas. (50-54: V.J. Pott 1937; 55: C.J. Ferreira 45; 57: A. Pott 2768). 
estigma pigmentado. Fruto assimétrico; estilete persistente, $0,37 \times 0,3 \mathrm{~mm}$, curto, pigmentado; semente $0,29 \times 0,23 \mathrm{~mm}$.

Distribuída nas regiões temperadas quentes, subtropicais e tropicais das Américas com inverno suave e verão ameno. Pode ocorrer dimorfismo do ápice (arredondado ou afilado) da fronde e haver até 8 frondes, formando uma colônia em forma de estrela. O material do Pantanal não possui ápice afilado nem 8 frondes unidas. Pode ocorrer em populações puras e florescer muito porém produz poucas sementes. Floresce de julho a agosto.

Material examinado - BRASIL: MATO GROSSO: Cáceres, Baía do Iate, planície de inundação do Rio Paraguai, V.J.Pott et al. 2047, 10/4/1993 (CPAP); Poconé, Rio Bento Gomes, ponte, para Porto Cercado, V.J. Pott et al. 1875, 14/4/1993 (CPAP); Cuiabá, UFMT, tanque de plantas aquáticas, origem estrada para Porto Cercado, A.L. Prado 2, 5/8/1992 (CPAP). MATO GROSSO DO SUL: Corumbá, faz. Leque, baía do Búfalo, V.J. Pott \&t M.P. Silva 1399, 21/6/ 1990 (CPAP); idem, MS 184, Estrada do Passo do Lontra, entre faz. Boa Sorte e faz. Baú, V.J. Pott et al. 1943, 12/8/1992 (CPAP); idem, BR 262, km 747, M.S. Lima 34, 20/11/1987 (COR); idem, Estrada inacabada para Forte Coimbra, MS 454, $10 \mathrm{~km}$ da BR 262, N.C. Bueno et a.1 400, 30/7/1992 (CPAP); idem, Lagoa do Jacadigo, final do Tamarineiro, V.J. Pott 1695, 21/5/1992 (CPAP); idem, Corixo Mutum, V.J. Pott et al. 351A, 29/9/1987 (CPAP); idem, Estrada MS 454, 9,3 km da BR 262, V.J. Pott \& A. Pott 2034, 13/2/1993 (CPAP); idem, Lagoa do Jacadigo, BR 262, km 735, V.J. Pott \& A. Pott 1863, 28/2/1993 (CPAP); idem, Lagoa do Jacadigo, próx. ao morro Tromba dos Macacos, S. Hamilton \& S. Sippel 26, 30/5/1993 (CPAP); idem, faz. Nhumirim, A. Pott 2768, 8/6/1987 (CPAP); idem, faz. Barrinhos, A. Pott 6436, 6/6/1993 (CH, CPAP, CTES, HBR, ICN, SI, $\mathrm{SP})$; idem, Porto Morrinho, braço do rio Paraguai, V.J. Pott et al. 1668, 7/5/1992 (CPAP); Ladário, Antiga CODRASA, quase no final do polder, $12 \mathrm{~km}$ da BR 262, V.J. Pott \& A. Pott 1980, 31/10/1992 (CPAP); Planície da baía Negra, polder da CODRASA, $12 \mathrm{~km}$ da BR 262, S. Hamilton \& S. Sippel 10, 22/8/1992 (CPAP); Miranda, BR 262, km 562, próx. à ponte do rio Miranda, V.J. Pott \& A. Pott 1673, 13/7/1992 (CPAP, CTES); idem, BR 262, km 562, próx. à ponte do rio Miranda, V.J. Pott \& A. Pott 1674, 13/7/1992 (CPAP, CTES); idem, BR-262, km 562, V.J. Pott \&
A. Pott 1992, 22/11/1992 (CPAP, CH, COR, HBR, ICN, SP, SPF). CHILE: Santiago do Chile, Philippi s.n., V.1857 (MO, Isolectótipo; K, Síntipo).

Wolffia Horkel ex Schleid., Beitr. Bot. 1:233. 1844. Espécie tipo: Wolffia michelii Schleid.

Plantas flutuantes livres na superfície da água a levemente submersas, com estágio latente submerso. Frondes globosas, ovóides, cilíndricas, cônicas em forma de barco ou noz; 1-2 frondes unidas; algumas espécies com pigmentos na epiderme; uma abertura cônica em forma de funil na base da fronde, da qual emergem frondes filhas, a partir do tecido meristemático; com ou sem estômatos. Raiz ausente. Flor 1 por fronde, originada numa cavidade na linha mediana no lado dorsal da fronde; flores sem profilo protetor; estame 1, antera bilocular, com pigmentos na linha de deiscência; ovário com 1 rudimento seminal ortótropo, estilete curto, estigma circular, côncavo. Fruto esférico, estigma persistente.

\section{Chave para as espécies de Wolffia}

1. Fronde globosa, flutuante, aplanada na face dorsal (superior), com 1 papila na linha mediana; fronde de cor verde escura e pigmentos castanhos na epiderme (bem visíveis em frondes secas)

W. brasiliensis

1. Fronde globosa, levemente submersa, não aplanada, com 2-3 saliências inconspícuas; fronde de cor verde clara, células grandes e sem pigmentos

W. columbiana

Wolffia brasiliensis Wedd., Ann. Sci. Nat. Bot. Ser. III 12:170. 1849.

Tipo: Brasil, Prov. de Matto Grosso, Villa Maria (atual Cáceres), M.H.A. Weddell, 7/1845 (STU, Lectóipo; L, MO!, Isolectótipos; K!, Síntipo)

Figuras 58-66, 86-87, 89.

Frondes flutuantes livres na superfície da água, globosas, ovóides a subcirculares, planas no lado dorsal, com 1 papila saliente ao centro em frondes estéreis, ausente em frondes floridas ou latentes, 0,6$1,50 \times 0,45-1,1 \mathrm{~mm}$ e $0,45-1,0 \mathrm{~mm}$ de espessura, $1-1,5$ vezes mais comprida que larga; lado dorsal com células pequenas, mais escuras e muitos estômatos anomocíticos; lado ventral convexo, células maiores e cor mais clara; toda fronde coberta de pigmentos castanhos, mais visíveis em frondes adultas ou se- 

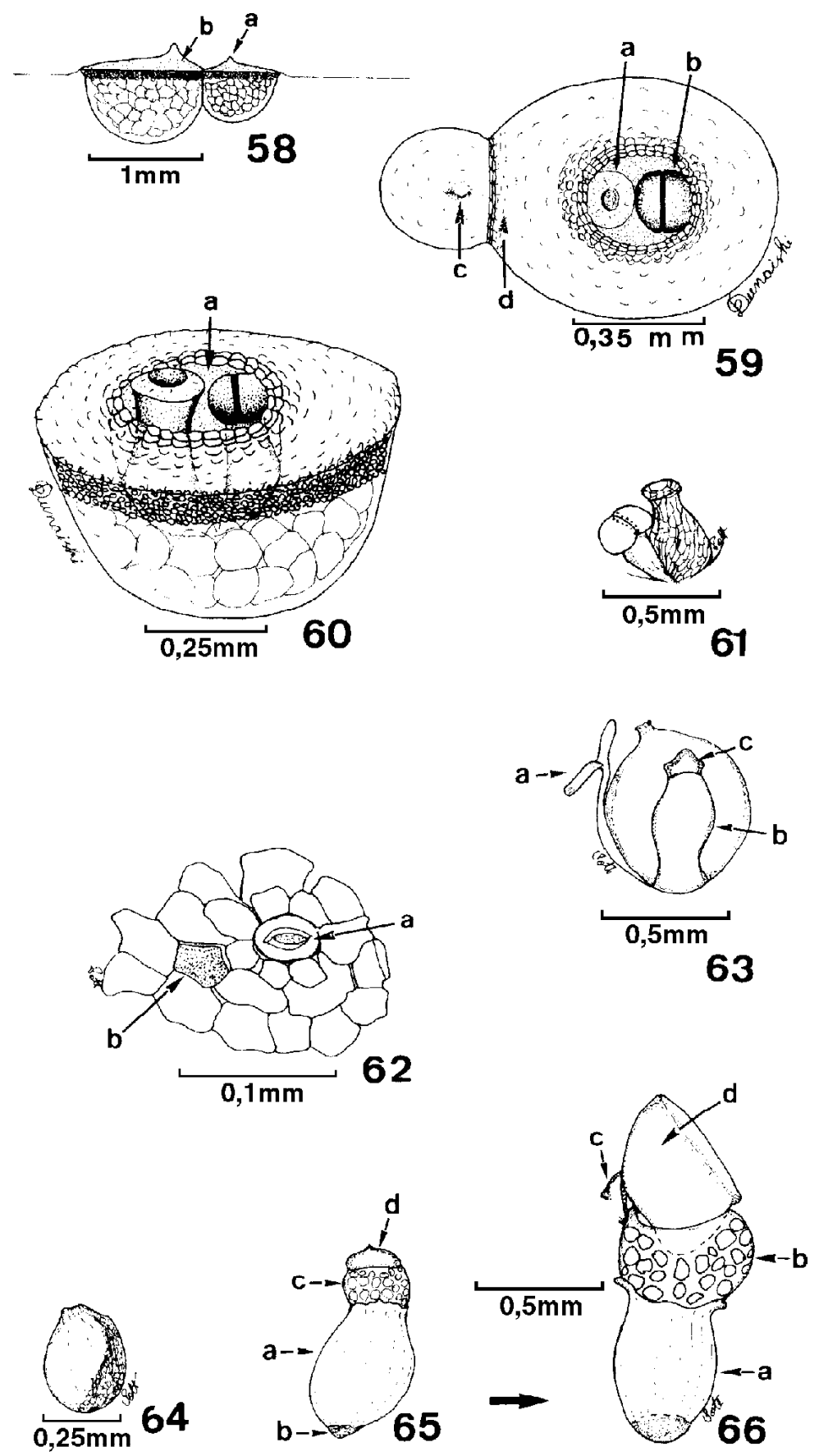

Figuras 58-66. Wolffia brasiliensis Weddell. 58. Hábito em relação à superfície da água: (a) papila, (b) pigmentos; 59. Vista superior da fronde: (a) estigma, (b) estame, (c) papila, (d) cavidade vegetativa; 60. Fronde em perspectiva superior: (a) cavidade floral; 61. Flor; 62. Epiderme: (a) estômato anomocítico, (b) células de pigmento; 63. Flor após fecundada: (a) estame senescente, (b) fruto imaturo, (c) opérculo; 64. Semente. 65. Semente germinando: (a) semente, (b) chalaza, (c) cotilédone;,(d) opérculo; 66. Germinação em fase adiantada: (a) semente, (b) cotilédone, (c) opérculo, (d) primeira fronde, $F_{0}$. (A.C.Cervi 3281). 
cas. Flor 1 ao centro, no lado dorsal da fronde; estame $0,37 \mathrm{~mm}$ compr.; ovário $0,37 \times 0,23 \mathrm{~mm}$. Fruto 0,42 x $0,27 \mathrm{~mm}$; semente $0,32 \times 0,23 \mathrm{~mm}$.

Distribuição tropical, subtropical e nas regiões temperadas quentes das Américas. $\mathrm{O}$ tamanho minúsculo das plantas e a presença ou ausência de papila na superfície da fronde já foram motivos de confusão taxonômica e vários sinônimos foram criados, os mais comuns sendo $W$. punctata Griseb. e $W$. papulifera C.H. Thomps. (Thompson 1898). Ocorre em lagoas e alagados rasos e em lugares perturbados. Geralmente é encontrada em associação com $W$. columbiana (submersa) e Lemna aequinoctialis, ou com ambas as espécies, mas em menor quantidade. É freqüentemente encontrada em águas eutrofizadas por fezes de animais, como em tanques de criação de jacarés ou próximo a porteiras e sedes de fazendas. Floresce de fevereiro a agosto.

Material examinado - BRASIL: MATO GROSSO: Cáceres, Villa Maria, M.H.A. Weddell, 7/1845 (MO 1768879, Isolectótipo; K, Síntipo); idem, Planície de inundação do Rio das Flechas, V.J. Pott et al. 2036, 19/4/93 (CPAP). MATO GROSSO DO SUL: Corumbá, Estrada do Abobral, entre faz. Baú e faz. S. Jorge, S. Hamilton \& S. Sippel 19, 28/4/1993 (CPAP); idem, Nhumirim, tanque do jacaré, V.J. Pott et al. 584, 11/9/1988 (CPAP, COR); idem, faz. Firme, A.C. Cervi et al. 3281, 21/8/1991 (CPAP, MBM, UPCB); idem, faz. Firme, lado oeste do aterro (estrada MS 228), A. Pott et al. 6167, 17/5/1992 (CPAP, CTES); idem, faz. Firme, MS 228, próx. $6 \mathrm{~km}$ da curva do Leque, V.J. Pott et al. 1945, 13/8/1992 (COR, CPAP, SP, SI, SPF); idem, faz. Nhumirim, baía da sede, N.C. Bueno 516, 5/6/1993 (CPAP, CH, COR); idem, faz. Nhumirim, lagoa de vazante, próx. à sede, A. Pott 6385, 5/6/1993 (CPAP, SP); idem, Estrada MS 454, V.J. Pott 1795, 7/5/1992 (CPAP); idem, faz. Fazendinha, MS 454, 11,5 km da BR 262, V.J. Pott et al. 1959, 14/8/1992 (CPAP, UPCB, MBM); idem, Estrada para Estação Ferroviária Albuquerque, 4,6 km da BR 262, periferia do Pantanal, V.J. Pott et al. 1847, 28/2/1993 (CPAP, ICN); idem, BR 262, km 735, pirizal, V.J. Pott et al. 1868, 28/2/1993 (CPAP); idem, Área do Posto Esdras, fronteira com Bolívia, V.J. Pott \& A. Pott 2012, 12/12/1992 (CPAP); Aquidauana, faz. Taboco, divisa com faz. Iguaçu, R.A. Mauro \& N.R. Guedes 94, 27/3/93 (CPAP).
Wolffia columbiana H. Karst., Bot. Unters. 1:103. 1865.

Tipo: Colombia, Santa Maria, H. Karsten. (STU, Lectótipo).

Figuras 67-76, 85, 88-89.

Frondes flutuantes livres, ligeiramente submersas ou sob vegetação flutuantes, simétricas, elipsóides, quase esféricas, sem papila, com 1-3 saliências inconspícuas quando ocorrem na superfície da água, $0,9-2,7$ x 0,7-2,3 mm, 1-1,3 vezes mais longa que larga; fronde sem pigmentos castanhos, cor verde clara, consistência dura, células grandes; quando florida, menor e aplanada dorsalmente. Flor 1, protogínica ,central no lado dorsal da fronde; estame $0,51 \mathrm{~mm}$ compr.; ovário $0,52 \times 0,10 \mathrm{~mm}$, estigma sem pigmentos. Fruto 0,50 x 0,27 mm; semente $0,45 \times 0,23 \mathrm{~mm}$.

Distribuição geográfica: nas regiões subtropicais e temperadas das Américas com inverno e verão brandos. Não apresenta variação na forma da fronde; o tamanho pode variar, de acordo com o habitat e a densidade das plantas. A cor clara, o hábito submerso, a forma quase esférica e as células grandes da fronde, servem para a identificação da espécie quando associada com $W$. brasiliensis. Geralmente associada com W. brasiliensis e Lemna aequinoctialis, que também ocorrem preferencialmente em locais com influência antrópica. Floresce de fevereiro a julho.

Material examinado - BRASIL: MATO GROSSO DO SUL: Corumbá, Estrada do Abobral, entre faz. São Jorge e faz. Baú, S. Hamilton \& S. Sippel 20, 28/4/ 1993 (CPAP, HBR, CTES); idem, Estrada MS 454, V.J. Pott et al. 1794, 7/5/1992 (CPAP, ICN, SPF, COR, SI); idem, faz. Bodoquena, BR 262, km 606,5, V.J. Pott et al. 1939, 12/8/1992 (CPAP); idem, faz. Fazendinha, MS $454,11,5 \mathrm{~km}$ da BR 262, V.J. Pott \& A.A. Bueno Sbr. 1965, 9/10/1992 (CPAP, CH); idem, BR 262, km 718, $800 \mathrm{~m}$ sul da entrada para Albuquerque, V.J. Pott 1997, 22/11/1992 (CPAP); idem, Lagoa do Jacadigo, A. Pott et al. 2891, 23/5/1987 (CPAP); idem, Estrada MS 454, 9,3 km da BR 262, V.J. Pott \& A. Pott 2020, 13/2/1993 (CPAP, MBM, SP, ICN); idem, Estrada MS 454, 13 km da BR 262, V.J. Pott \& A. Pott 2029, 13/2/1993 (CPAP, UPCB); idem, Lagoa do Jacadigo, próx. ao morro Tromba dos Macacos, S. Hamilton \& S. Sippel 27, 30/5/ 1993 (CPAP); idem, faz. Nhumirim, A. Pott 2770, 8/7/ 1987 (CPAP); idem, faz. Firme, Estrada MS 228, lado oeste do aterro, A. Pott et al. 6329, 17/5/1992 (CPAP); Aquidauana, faz. Taboco, fronteira com faz. Iguaçu, R.A. Mauro \& N.R. Guedes 95, 27/3/1993 (CPAP). 

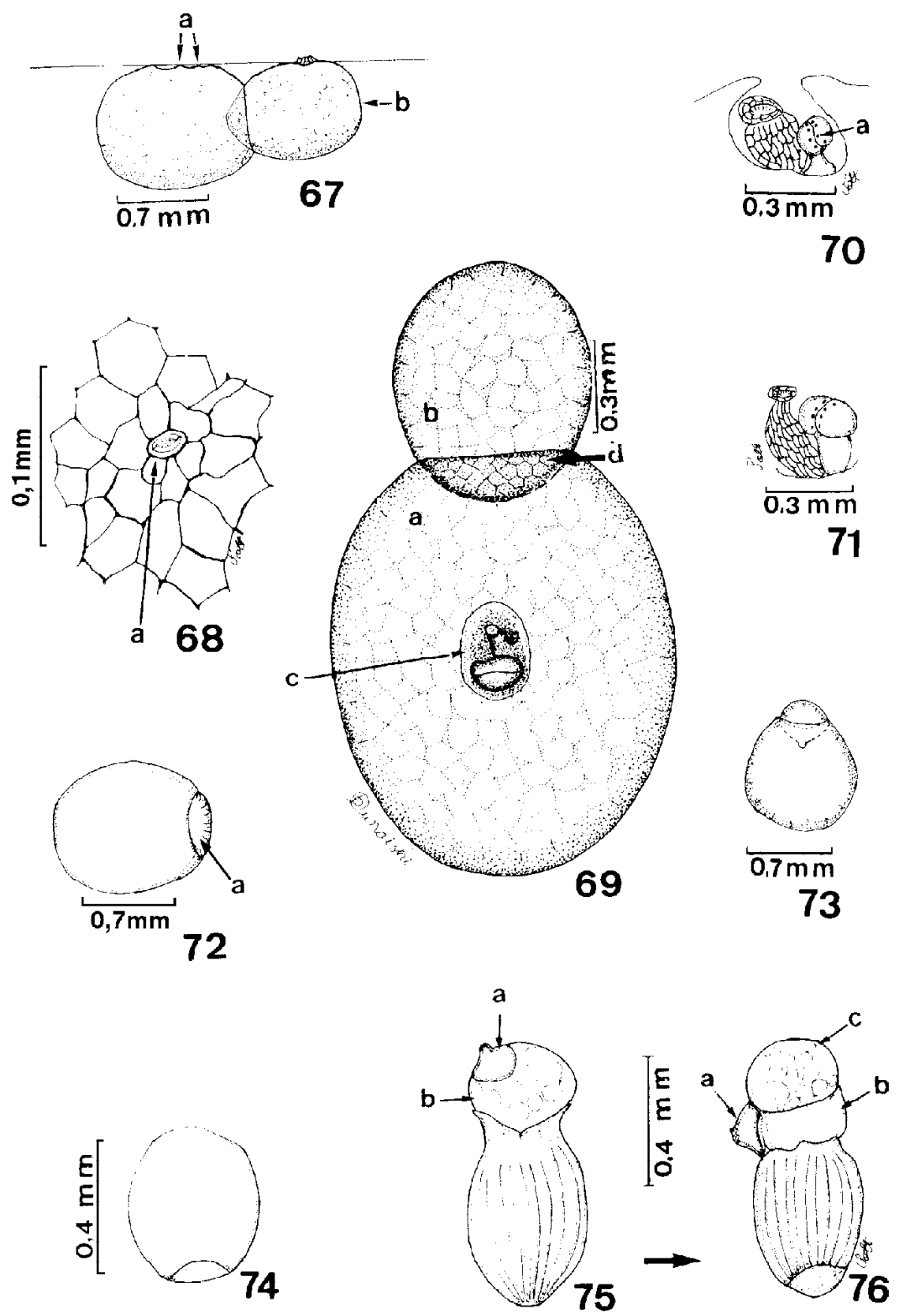

Figuras 67-76. Wolffia columbiana Karsten. 67. Hábito em relação à superfície da água: (a) dentículos, (b) fronde fértil; 68. Epiderme: (a) estômato anomocítico; 69. Vista dorsal de fronde fértil: (a) fronde-mãe, $\mathrm{F}_{0}$, (b) fronde-filha, $\mathrm{F}_{1}$, (c) cavidade floral, (d) cavidade vegetativa; 70 Flor: (a) antera com pigmentos; 71. Flor; 72. Fronde: (a) cavidade vegetativa; 73. Fronde (diafanizada); 74 . Semente; 75. Semente germinando: (a) opérculo, (b) fronde; 76. Semente germinando: (a) opérculo, (b) cotilédone, (c) fronde. (V.J. Pott 1846). 

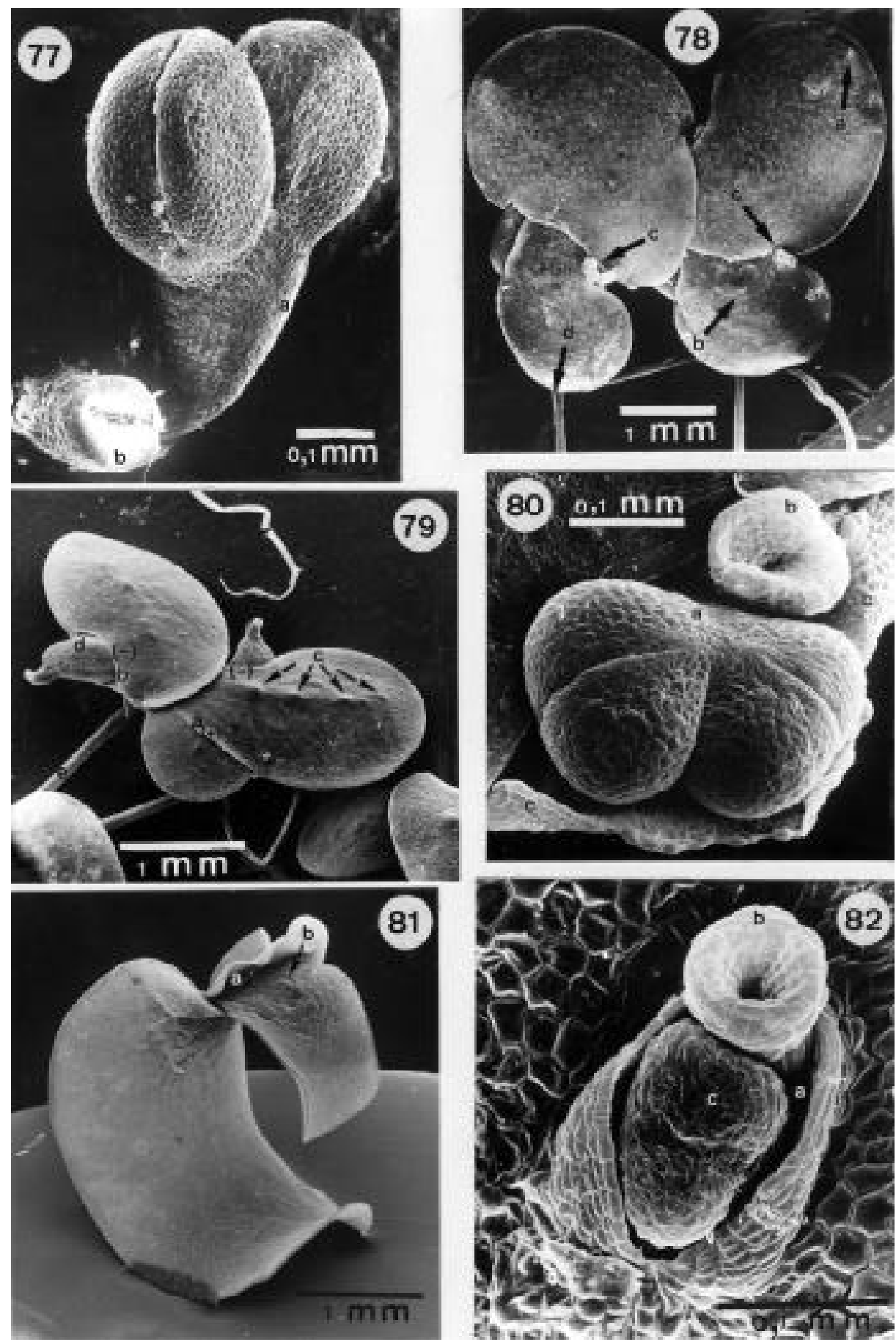

Figuras 77-82. Fotos ao MEV. 77. flor de Spirodela intermedia: (a) estame, (b) estigma; 78. Lemna aequinoctialis: (a) papila no ápice da fronde, (b) papila sobre o nó, (c) flor, (d) raiz; 79-80. Lemna valdiviana. 79. Fronde: (a) cavidade vegetativa (+), (b) cavidade floral (-), (c) linha de papilas, (d) fruto, (e) raiz; 80. Flor: (a) estame, (b) estigma, (c) lábio inferior da cavidade floral; 81-82. Wolffiella welwitschii. 81. Fronde: (a) cavidade vegetativa, (b) fronde-filha com iniciação floral; 82. Fronde: (a) cavidade floral, (b) estigma, (c) estame. 

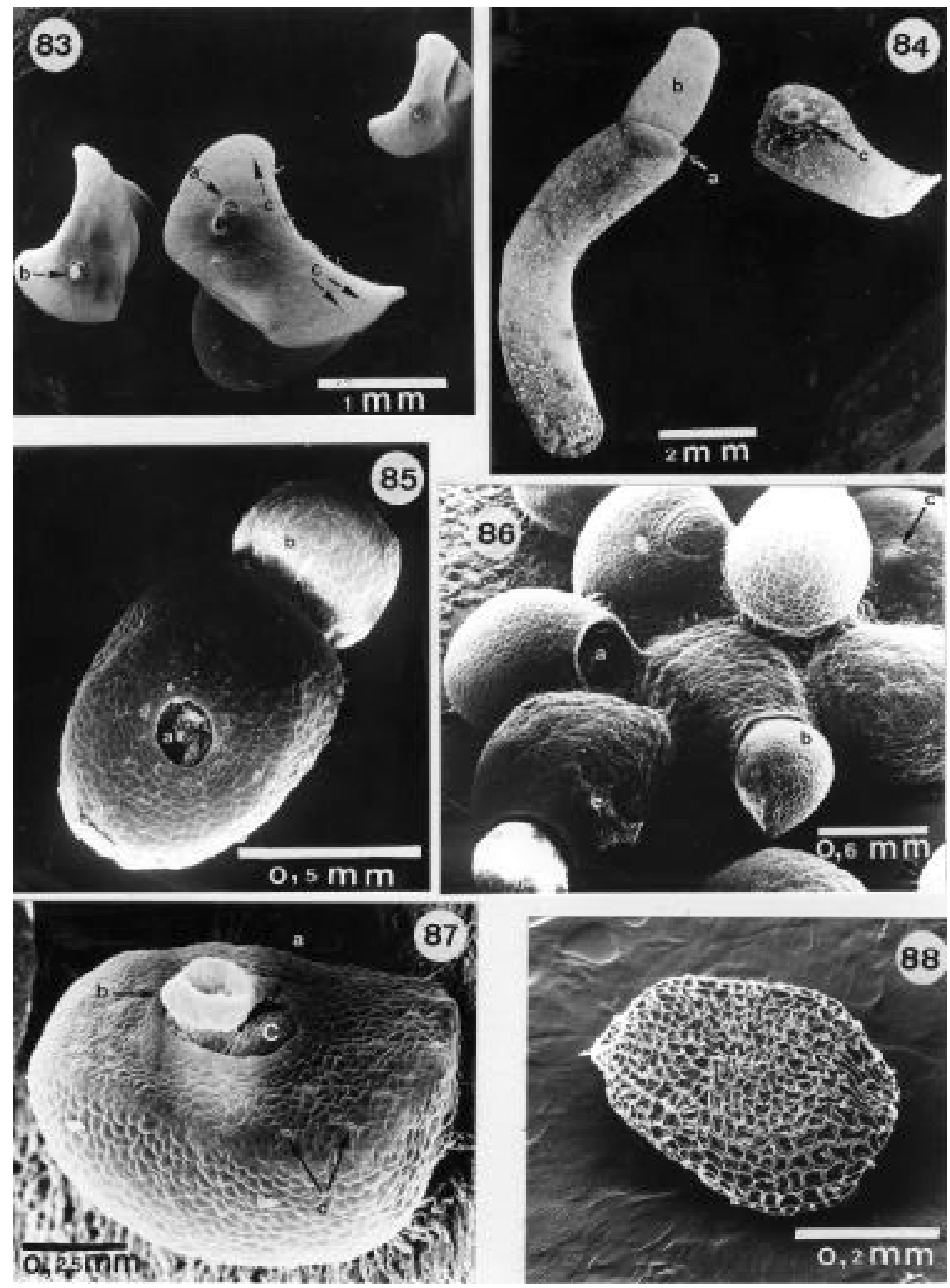

Figuras 83-88. Fotos ao MEV. 83. Wolffiella lingulata: (a) estame, (b) estigma, (c) células de pigmento; 84. Wolffiela oblonga: (a) cicatriz do estípite, (b) fronde-filha, (c) estame; 85. fronde fértil de Wolffia columbiana: (a) cavidade floral, (b) fronde-filha quase se desprendendo da fronde-mãe; 86-87 Wolffia brasiliensis. 86. frondes estéreis: (a) cavidade vegetativa, (b) fronde-filha; 87 . fronde fértil: (a) cavidade floral, (b) estigma, (c) antera, (d) estômato anomocítico; 88. semente de W. columbiana. 


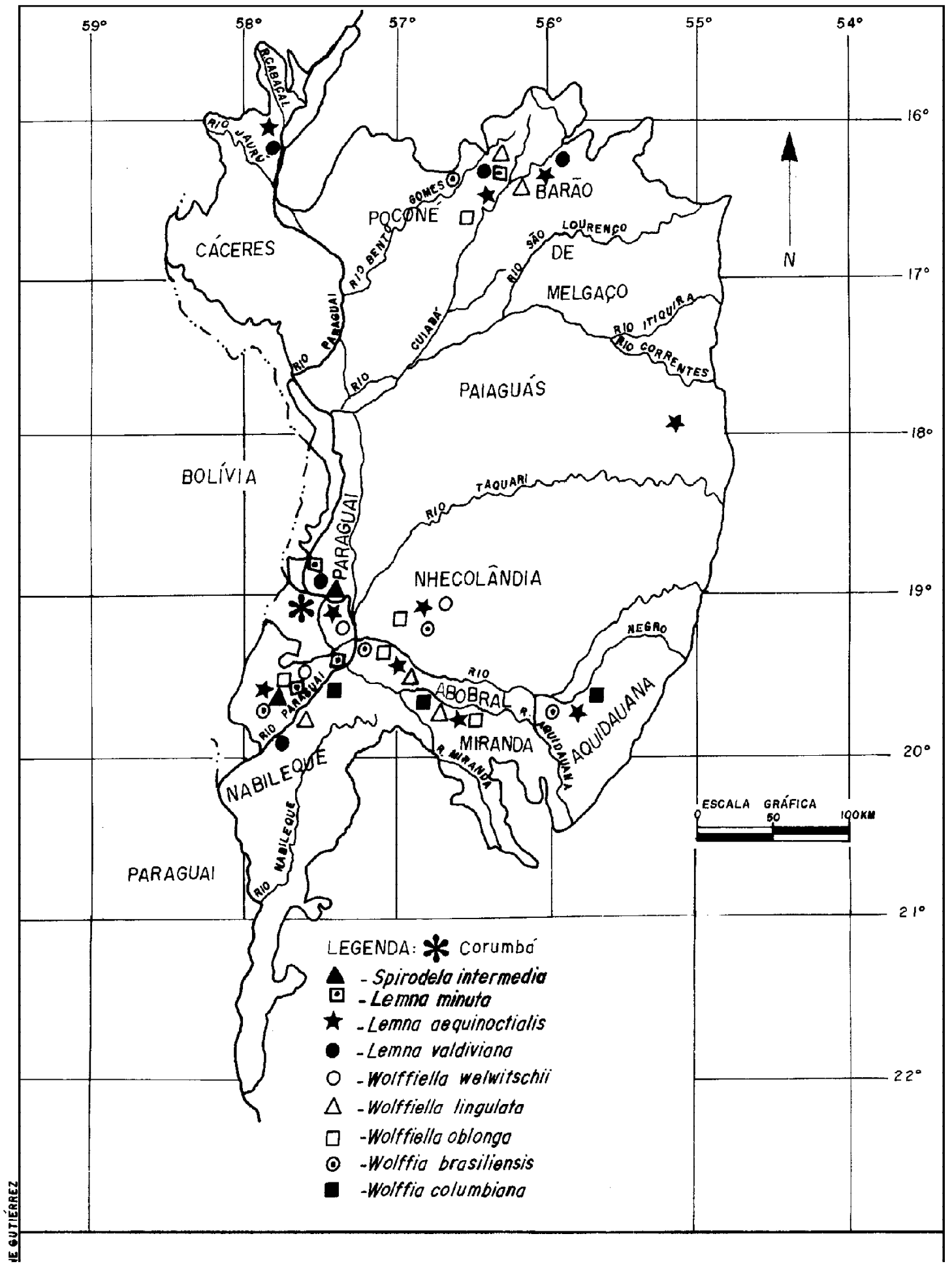

Figura 89. Distribuição geográfica de Lemnaceae no Pantanal. 
Agradecimentos - Ao Centro de Microscopia Eletrônica da UFPR, nas pessoas de Vera R. Pionteke, Profa. Daura R. E. Stofella, Prof. Dr. Yedo Alquini e Profa. Cleusa Bona, pela ajuda no preparo do material e fotografia ao microscópio eletrônico de varredura. Ao amigo botânico Antônio Dunaiski Jr., pela colaboração com muitas das ilustrações. Ao Dr. Elias Landolt, "Pai das Lemnaceae", pela pronta colaboração, bibliografia e a valiosa coleção viva. Ao Antônio A. Bueno Sobrinho, pela ajuda no Herbário e no cultivo de Lemnáceas. Aos colegas da biblioteca do CPAP, Romero Amorim e Helena B. Aderaldo pela bibliografia solicitada. Aos amigos Drs. Ulrike Nolte (UFMT) e Rainer Haase (Max Planck Institut) por apoio a viagem de coleta. À amiga Norma C. Bueno, pelo estímulo e companheirismo nas coletas no Pantanal.

\section{Referências bibliográficas}

CADAVID-GARCIA, E.A. 1984. O clima no Pantanal matogrossense. Circular Técnica 14. EMBRAPA/UEPAE de Corumbá, Corumbá.

CHASE, M.W., DOUGLAS, E.S., OLMMSTEAD, R.J., MORGAN, D., LES, D.H., MISHLER, B.D., DUVALL, M.R., PRICE, R.A., HILLS, H.G., QIU, Y.L., KRON, K.A., RETTING, J.H., CONTI, E., PALMER, J.D., MANHART, J.R., SYTSMA, K.J., MICHAELS, H.J., KRESS, W.J., KAROL, K.G., CLARK, W.D., HEDREN, M., GAUT, B.S., JANSEN, R.K., KIM, K.J., WIMPEE, C.F., SMITH, J.F., FURNIER, G.R., STRAUS, S.H., XIANG, Q.Y., PLUNKETT, G.M., SOLTIS, P.S., SWENSEN, S.M., WILLIAMS, S.E., GADEC, P.A., QIUINN, C.J., EGUIARTE, L.E., GOLENBERG, S.W., BARRETT, S.C.H., DAYANANDAN, S. \& ALBERT, V.A. 1993. Phylogenetics of seed plants: an analysis of nucleotide sequences from the plastid gene rbcL. Ann. Mo. bot. Gdn 80:528-580.

COOK, C.D.K. 1990. Aquatic Plant Book. SPB Academic Publishers, The Hague.

DAHLGREN, R.M.T., CLIFFORD, H.T. \& YEO, P.F. 1985. The families of the Monocotyledons: Structure, Evolution, and Taxonomy. Springer-Verlag, Berlin.

DAUBS, E.H. 1965. A monograph of Lemnaceae. Tese de doutorado, University of Illinois, Illinois.

DEN HARTOG, C. \& VAN DER PLAS, F.A. 1970. Synopsis of the Lemnaceae. Blumea 18:355-368.

DUMORTIER, B.C.J. 1827. Florula Belgica. J. Casterman, Tournay.

ENGLER, A. 1877. Vergleichende Untersuchungen über die morphologischen Verhältnisse der Araceae. Nov. Acta Acad. Caesar. Leop. Carol. 39:159-232.

ENGLER, A. 1889. Lemnaceae (Wasserlinsen). In Die natürlichen Pflanzenfamilien (A. Engler \& K. Prantl, eds.), v.2, p.154-164.

FONT QUER, P. 1953. Diccionário de Botánica. Editorial Labor, Barcelona.
GIARDELLI, M.L. 1969. Lemnaceae. In Flora Patagonica (M.N. Correa, ed.). Coleccion Científica del INTA 8:93-101.

GIARDELLI, M.L. 1972. "Wolffia brasiliensis", espécie de Lemnáceas nueva para la flora de Argentina. Darwiniana 17:596-797.

GRAY, S.F. 1821. Lemnadeae. In A natural arrangement of British plants, v.2, p.729-730.

HEGELMAIER, F. 1868. Die Lemnaceen, eine monographische Untersuchung. Verlag W. Engelmann, Leipzig.

HEGELMAIER, F. 1878. Lemnaceae. In Flora Brasiliensis (C. F. P. Martius \& A.G. Eichler, eds.). F. Fleischer, Lipsiae, v.3, pars 2, p.1-23.

HILLMAN, W.S. 1961. The Lemnaceae, or duckweeds. Bot. Rev. 27:221-287.

HOLMGREN, P.K., HOLMGREN, N.H. \& BARNETT, L.C 1990. Index Herbariorum. Part I: The Herbaria of the World. New York Botanical Garden, New York, $8^{\mathrm{a}}$ ed.

LANDOLT, E. 1980. Key to the determination of taxa within the family of Lemnaceae. Veröff. geobot. Inst., Zürich 70:13-21.

LANDOLT, E. 1981. Distribution of the family Lemnaceae in North Carolina. Veröff. geobot. Inst., Zürich 77:112-148.

LANDOLT, E. 1986. Biosystematic investigations in the family of duckweeds (Lemnaceae) - The family of Lemnaceae - a monographic study v.1. Veröff. geobot. Inst., Zürich 71:1566.

LANDOLT, E. \& KANDELER, R. 1987. Biosystematic investigations in the family of duckweeds (Lemnaceae) - The family of Lemnaceae - a monographic study v.2. Veröff. geobot. Inst., Zürich 95:1-638.

LINNÉ, C. 1753. Species plantarum. Imprensis Laurentii Salvii, Stockholm, v.2, p. 970-971.

MAHESHWARI, S.C. 1956. The endosperm and embryo of Lemna and systematic position of the Lemnaceae. Phytomorphology 6:51-55.

MAHESHWARI, S.C. 1958. Spirodela polyrrhiza: the link between the aroids and the duckweeds. Nature 181:1745-1746.

MAHESHWARI, S.C. 1959. Systematic position of the family Lemnaceae. Proc. IX Internat. Bot. Congr. v.2, p.246-247.

MAYO, S., BOGNER, J. \& BOYCE, P. 1995. The Arales. In Monocotyledons - Systematics and Evolution (P.J. Rudall, P.J. Cribb, D.F. Cutler \& C.J. Humphries, eds.). Royal Botanic Gardens, Kew. p.277-286.

MELCHIOR, H. \& WERDERMANN, E.1964. Engler's Syllabus der Pflanzenfamilien. Gebr. Bornträger, Berlin, 2:596-598.

MICHELI, P.A. 1729. Nova plantarum genera. Typis Bernardi Paperinii, Florentiae

SCHLEIDEN, M.J. 1839. Prodomus Monographiae Lemnacearum oder Conceptus generum atque Specierum. Linnaea 13:385392.

THOMPSON, C.H. 1898. A revision of the American Lemnaceae occurring north of Mexico. Rep. Mo. bot. Gdn 9:21-42. 